1894

c. 2

NMAA

N
$68 \varnothing$
$A 6$
1894
$C .2$
NMAA

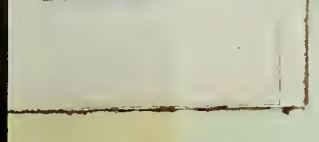




\section{है}

DESCRIPTIVE CATALOGUE OF THE PERMANENT COLLECTIONS OF WORKS OF ART ON EXHIBITION IN THE GALLERIES

SECOND EDITION

PHILADEI.PHIA M D C C X C I V

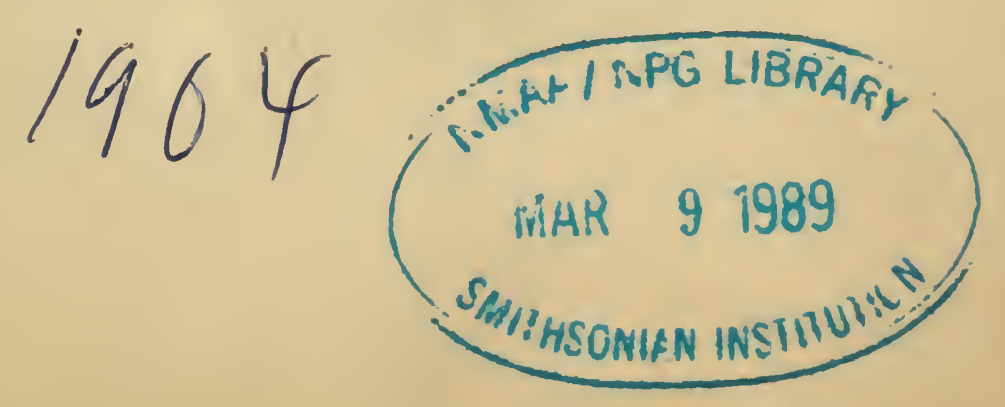




\title{
MANAGEMENT OF THE ACADEMY
}

\author{
के \\ 1894 \\ PRESIDENT \\ EDWARD H. COATES \\ VICE-PRESIDENT \\ CLARENCE H. CLARK
}

DIRECTORS

CLARENCE H. CLARK

WILLIAM B. BEMENT

E. BURGESS WARREN

CHARLES HENRY HART

JOHN H. PACKARD, M.D.

HENRY WHELEN, JR.
JOHN H. CONVERSE

CHARLES HARE HUTCHINSON

ALEXANDER BIDDLE

FRANCIS W. LEWIS, M.D.

THEOPHILUS P. CHANDLER, JR.

TREASURER

HENRY WHELEN, JR.

SECRETARY AND MANAGING DIRECTOR

HARRISON S. MORRIS

SOLICITOR

JOHN G. JOHNSON

COMMITTEE ON EXHIBITIONS

FRANCIS W. LEWIS, M.D., Chatrman

E. BURGESS WARREN

JOHN H. PACKARD, M.D.

CHARLES HENRY HART 


\section{CONTENTS.}

Introduction . . . . . . . . . . . . . . . . page 4

American Pictures . . . . . . . . . . . . . . " 7

British Pictures . . . . . . . . . . . . " 45

Continental Pictures before the Nineteenth Century . . . " " 54

Continental Pictures of the Nineteenth Century . . . . " " 68

American Sculpture . . . . . . . . . . . . . " 79

British Sculpture . . . . . . . . . . . . . " 85

Continental Sculpture before the Nineteenth Century . . " " 86

Continental Sculpture of the Nineteenth Century . . . " " 92

Sculpture Loaned . . . . . . . . . . . . . . " 95

Harrison Earle Collection of Pictures, Loaned . . . . " " 96

Honors awarded by the Temple Fund . . . . . . " 103

Academy Medal awards . . . . . . . . . " " I03

Academy Album . . . . . . . . . . . . . . "IO4

\section{EXPLANATION OF REFERENCES.}

Acadcmy Album. Reproductions of twenty-eight pictures, with text.

For sale at the Desk. Price, $\$ 1.00$. See last page.

Library, first floor to right of entrance.

Number in centre of page, number of the work.

Number on right of page, number of wall where picture is hung.

Print Room, first floor to right of entrance.

Size of pictures given in inches.

Right and loft means right and left of observer.

\section{ABBREVIATIONS.}

A., American. B., British. C., Continental prior to I gth century. D., Continental, I gth century. L., Loaned. P. A. F. A., Pennsylvania Academy of the Fine Arts. P.A., Academician P. A. F. A. A.P.A., Associate P.A.F.A. P.R.A., President Royal Academy, London. R.A., Royal Academician. A.R.A., Associate Royal Academy. N. A. D., National Academy of Design, New York. P.N.A., President N.A. D. N.A., Academician N.A.D. A.N.A., Associate N. A. D. 


\section{INTRODUCTION.}

The Pennsylvania Academy of the Fine Arts is the oldest institution devoted to art in the United States. It was founded in $\mathrm{I}_{80} 5$, and chartered the next year, but actually dates from I79I, when Charles Willson Peale attempted to organize in Philadelphia a School for the Fine Arts. This purpose, though supported by Ceracchi the Italian sculptor then in America, William Rush, and other artists, was not successful; but out of it grew, in I794, the Columbianum, and in the same year the first public exhibition of paintings in Philadelphia was held by that association in Independence Hall. The Columbianum existed in a tentative way for several years, and Peale's interest in a school, society, or academy to advance the interests of the fine arts never abated. Hence, when some public-minded citizens of Philadelphia, chiefly lawyers, determined that the time for making a pronounced effort toward this end had arrived, it was to Mr. Peale that they turned, and the formative meeting was held in his rooms in the old State House. This occurred in 1805 , and on March 28, 1806, the Academy was incorporated. Its first President was George Clymer, one of the signers of the Declaration of Independence, who held the position for eight years. His successors have been: Judge Joseph Hopkinson, the accomplished author of Hail Columbia, who held the office from I 8 I 3 to I 842 ; Joseph Dugan, from 1842 to 1845 ; Edward L. Carey, I845; Joseph R. Ingersoll, from I 846 to 1852 ; Henry D. Gilpin, from 1852 to 1859 ; Caleb Cope, from 1859 to I87 I; James L. Claghorn, from I872 to I884; George S. Pepper, from I 884 to 1890 ; and Edward H. Coates, elected in 1890 . Portraits of all the earlier Presidents except Messrs. Hopkinson, Dugan, and 
Ingersoll now hang in the Directors' room, and it is much desired that the omissions may ultimately be filled.

The works of art belonging to the Academy, which are catalogued in the following pages, have slowly accumulated during the eighty-nine years of its existence, except in the cases of the Carey and Temple collections. The Carey collection was formed by the fourth President of the Academy, who was one of the earliest patrons of the fine arts in the country. Mr. Carey's sister married Charles Robert Leslie, R.A., who was born in England while his parents were temporarily sojourning there, and who subsequently adopted England as his home. It was through his aid that the examples of the British school of painters now owned by the Academy were obtained. Mr. Carey was also a judicious patron of American artists, as is indicated by the pictures of the American school in the Carey collection. These works were purchased from the late Mr. Henry C. Carey, to whom they had been bequeathed by his brother.

The Temple collection is the result of a foundation established by Mr. Joseph E. Temple in 1880 , and now numbers thirty-four pictures, to which will be added from time to time other representative paintings by American artists, from the annual exhibitions of the Academy. These, with the pictures and sculpture brought together from many other sources, render the galleries of the Academy equal in importance and in artistic value to any in the country.

The plan adopted for the catalogue is a very simple one. The pictures are divided into three classes-American, British, and Continental. The last class is subdivided into artists before, and artists of, the nineteenth century. Each division is arranged alphabetically according to the artists, and the pictures are numbered consecutively. The same classification has been followed with the sculpture. Thus, American, A I to A I99; British, B 200 to B 299; Continental before the nineteenth century, C 300 to C 399; Continental of the nineteenth century, D 400 to D 499 . The number of the picture is in the centre of the page. The corresponding number on the right-hand side of the page is the number of the wall upon which the picture hangs. 
In addition to the works here catalogued, the Academy possesses a fine collection of casts in the school department; some interesting original drawings; the Phillips collection of 40,000 etchings and engravings in the Print Room; a complete set of the Arundel Society publications; and the following small but valuable collection of miniatures and medallions hung in the Directors' room :

\section{MINIATURES AND MEDALLIONS.}

I. Sir John Zouch, last Baron Codnor. By Sir Isaac Oliver, I6 2.

2. Elihu Etting. Artist unknown, I770.

3. Reuben Etting. By James Peale, I792.

4. Frances Gratz Etting. By James Peale, I792.

5. Solomon Etting. By Benjamin Trott, I 798.

6. Joseph Marx. By Edward Greene Malbone, 1800.

7. Asher Marx. By Edward Greene Malbone, I803.

8. Benjamin Etting. By a Chinese artist, 1826.

Presented by Frank Marx Etting, 1886.

9. John Ross. Painter unknown. Paris, I786.

ı. Clementina Ross. By Robert Fulton. Paris, I786.

Bequest of Elizabeth Mifflin, i 886.

I I. Daniel Webster. By Richard M. Staigg. Washington, I 844 . Presented by Alexander Biddle, I892.

I2. Falls of Niagara. Enamel by William Russell Birch.

Bequest of Eliza Howard Burd, I 860.

I3. Venus. Enamel by William Russell Birch.

Presented by John M. Staney, I 869 .

14. Napoleon. Medallion. Silver in Glass. From the Count de Survilliers collection. Presented by John J. Breban, I 860.

I 5. Joseph E. Temple. Cameo. Rome.

Presented by James E. Caldwell \& Co., 1886.

July, 1894 . 


\section{DESCRIPTIVE CATALOGUE}

\section{AMERICAN PICTURES.}

\section{के \\ Washington Allston, P.A., A.R.A.}

Born in Waccamaw, S.C., November 5, I779; died in Cambridge, Mass., July 9, I843. Graduated from Harvard, I800. Went to England, I801, and studied at Royal Academy. Afterwards visited Rome, whence he returned to America in I809. Subsequently resided in England from I8II to ISI8, and finally took up his residence in Massachusetts.

\section{A I}

Dead Man restored to Life by touching the

Bones of the Prophet Elisha.

Exhibited at British Institution, I 813 , and awarded a prize of £200. Purchased by P. A. F. A., in 1816 , for $\$ 3500$. Reproduced in Academy Album.

\section{Nina G. Batcheler.}

Born in Frankfort, Ky. Studied at P. A. F. A. and in Paris.

A 2

Love Disarmed.

Signed on front, N. Batcheler. Paris Salon, i 885. Purchased by Temple Fund, 1885 . 


\section{Henry Singlewood Bisbing.}

Born in Philadelphia, January 3I, I849. Studied in P. A. F. A. Went to Munich in $S_{776}$, and later to Brussels, where he became a pupil of De Haas. After a visit to this country in $I S_{3}$, he went to Paris, where he has since lived. Member of the Committee on Fine Arts, Universal Exposition, Paris, I889. Temple Gold Medal, P. A. F. A., I 892. Medal, World's Columbian Exposition, 1893 .

In the Meadow.

\section{A 3}

Signed on front, H. S. Bisbing, -88. Paris Salon, 1889. Presented by Col. Thomas Fitzgerald, I89 I.

\section{Henry Collins Bispham, A.P.A.}

Born in Philadelphia, June 9, I84I ; died in Rome, Italy, December 23, I882. Studied with William T. Richards in Philadelphia, and with Otto Weber in Paris.

The Lion Sultan.

\section{A 4}

Signed on front, H. C. Bispham, Paris, 1879. Paris Salon, I879, and Royal Academy, London, I880.

Presented by Mrs. Bloomfield Moore, I 883.
65

Canvas, $79 \times 138$. 


\section{William Mason Brown.}

Born in Troy, N.Y., September I4, I830. Studied color and design with an ornamental and decorative painter, and portraiture with a local artist. Removed to Newark, N.J., with his former master, and began landscape painting. Subsequently directed his attention to still-life, in which branch he has gained celebrity.

Fruit and Art Objects.

Signed on front, W. M. Brown. Purchased by Temple Fund, I 889 .

\section{William Merritt Chase, N.A.}

Born in Johnson Co., Ind., November I, I 849. Studied with Hayes, portrait painter, Indianapolis, I869; J. O. Eaton, New York, I870; at National Academy of Design, under Prof. Wilmarth, 1870 . Went to Munich in 1872 and studied with Wagner, and Piloty. Returned to America in 1878 . President Society of American Artists; Member National Acadeny of Design in City of Nunich; Nember American Water-Color Society, New York Etching Club and Painters in Pastel. Received Medals at Munich Academy; Gold Medal, Mechanics' Institute, Boston, I880; Honorable Mention, Paris Salon, I882; Third Class Medal, Munich, I883; and Silver Medal, Universal Exposition, Paris, 1889. Member International Board of Judges, World's Columbian Exposition, 1893. Hors Concours, Paris Salon.

\section{A 7}

China Vase and Copper Kettle.

Canvas, $18 \times 22$.

Signed on front, Wm. M. Chase. Purchased by Temple Fund, I 892 .

\section{Seth Wells 'Cheney, A.N.A.}

Born in South Manchester, Conn., November 26, I810; died in same place, September 10, 1856 . Visited Europe several times. Noted for his crayon portraits. 


\section{A 8}

Library.

Daughter of Vincenzo Camuccini.

Engraved by John Cheney for The Gift, I843. Carey Collection.

\section{Thomas Shields Clarke.}

Born in Pittsburgh, Pa., April 25, 1860. Studied at Art Students' League, New York; afterwards in Italy and at the École des Beaux-Arts, Paris, with Gérôme, Dagnan-Bouveret, and Jules Lefebvre. Honorable Mention at the Berlin International Art Exhibition, I891. Medal of Honor, Madrid International Exhibition of Fine Arts, I892. Medal, World's Columbian Exposition, I 893 .
A Fool's Fool.
A 9
28
Canvas, $39 \times 82$.

Signed on front, Thos. Shields Clarke, Florence, February, -87. Paris Salon, I 887.

Presented by Charles J. Clarke, I 888.

\section{James G. Clonney, A.N.A.}

Elected A. N. A. I834; died I867. Dunlap, History of the Arts of Design, I834, mentions him as a "miniature painter, New York."

\section{Militia Training. \\ A Io \\ Signed on front, James G. Clonney, I84I. Engraved by Joseph Ives Pease for The Gift, I845. Carey Collection.}

\section{George H. Comegys.}

Born in Maryland; died at Pennsylvania Hospital, Philadelphia. Pupil of Neagle. First print issued by American Art Union taken from his picture, The Artist's Dream.

\section{The Ghost Story.}

\section{A II}

Engraved by Joseph Ives Pease for The Gift, I840. Carey Collection. 


\section{A $12 \quad 102$}

The Little Plunderers.

Carey Collection.

\section{Thomas Bigalow Craig.}

Born in Philadelphia, February I4, I849.

\section{A 13}

Evening.

Canvas, $38 \times 68$.

Signed on front and back, Thos. B. Craig, i 887 . Temple Collection. The original having been destroyed, the present copy was

Presented by the Artist, I 887.

\section{William Parsons W. Dana, N.A.}

Born in Boston, February $18, \mathrm{I} 833$. Went to Europe, $1852-53$. Studied in the École des Beaux-Arts and with Le Poittevin. Returned to this country in I862. Lives at present in Paris. Medals, Universal Exhibition, Paris, I878 and 1889, and Boston Exhibition, 1881. Landscape Prize, P. A. F. A., I88 I.
A I4
62

Off the French Coast. Moonlight Effect.

Canvas, $42 \times 84$.

Signed on front, W. P. W. Dana, Paris, I 881 . Paris Salon, I 882.

Presented by Atherton Blight, 1882 .

\section{Jane Sully Darley.}

Born in New York, 1810; died in Philadelphia, February 25, 1887. Eldest child of Thomas Sully. 


\section{A 15}

Female Head.

Signed on back, Jane C. Darley, Pinxt, i 840. Presented by the Artist, I 845 .

Canvas, $17 \times 19$

\section{Charles Harold Davis.}

Born in Amesbury, Mass., I856. Studied in the Museum of Fine Arts, Boston, and in Paris with Boulanger and Lefebvre. Member Society American Artists. Received Gold Medal, American Art Association. New York, I886; prize, $\$ 2000$, same place, I887; Honorable Mention, Paris Salon, I887; Silver Medal, Universal Exposition, Paris, I889; Palmer Prize, $\$ 500$, Chicago, I89o; Gold Medal, Mechanics' Fair, Boston, same year; Medal, World's Columbian Exposition, 1893.

\section{A 16}

The Brook.

Canvas, $72 \times 115$.

Signed on front, C. H. Davis, I890. Paris Salon, I89o.

Reproduced in Academy Album. Purchased by Temple Fund, I 89 I.

\section{Thomas Doughty.}

Born in Philadelphia, July 9, I793; died in New York, July 24, 1856. Engaged in the leather business in early life. About 1820 adopted art as a profession. Spent several years abroad, painting in London and Paris, and acquired high reputation for the silvery tone of his pictures.

A $\quad$ I7

On the Susquehanna.

A 18

Landscape.

Carey Collection.

A I9

Landscape.
IOI

Canvas, $18 \times 28$.

102

Canvas, $18 \times 25$.

102

Canvas, $15 \times 21$.

Signed on front, T. Doughty, I829-30. Carey Collection. 


\section{A $20 \quad 102$}

View near Hartford, Conn.

Canvas, $17 \times 24$.

Presented by Cephas G. Childs, I 828 .

A $2 I$

Landscape.
IOI

Canvas, $18 \times 27$.

\section{Frank Duveneck.}

Born 1847. Pupil of Prof. Dietz, at Munich. Member Society American Artists. Medal, World's Columbian Exposition, I893.

\section{A 22}

60

Turkish Page.

Canvas, $42 \times 60$.

Signed on front, F. Duveneck, Munich, 1876. Purchased by Temple Fund, 1894.

\section{Thomas Eakins.}

Born in Philadelphia, July 25, I844. Studied in Paris with Gérôme, Bonnat, Dumont, and at the École des Beaux-Arts. Instructor in P. A. F. A., I876 to I886. Medal, World's Columbian Exposition, I 893 .

$\begin{array}{llr}\text { The Pathetic Song. } & \text { A } 23 & 7 \\ & \text { Canvas, } 33 \times 46 .\end{array}$

Loaned by Edward H. Coates.

\section{Jacob Eichholtz, P.A.}

Born in Lancaster, Pa., I776; died May II, I8 42 . Studied with a sign-painter in his native town, and finally with Stuart, in Boston. Also received advice from Sully.

Portrait of Rev. John Gottlieb
A 24

Ernestus Heckewelder.

Moravian missionary. Born 1743 ; died 1823 . Painted at Bethlehem, Pa., I 823. Signed on front, E, 1823 . Presented by William L. Elkins, I 893 . 


\section{William Graham.}

Born in New York. Has spent many years in Rome, painting generally Roman and Venetian landscapes.

\section{A $25 \quad$ Print Room}

\section{Outside the Porta del Popolo, Rome. \\ Canvas, $12 \times 16$.}

Signed on front, W. Graham, Rome, 1874-75.

Presented by Mr. and Mrs. John W. Field, 1887.

\section{Henry Peters Gray, P.N.A.}

Born in New York, June 23, 1819; died there November 12, 1877. Began study of art under Huntington, 1838 . Went to Europe in 1839 . Returned and painted portraits from $\mathrm{I} 843$ to $\mathbf{I} 846$. Made a second visit abroad. President of N. A. D., I 869 to I87 I, in which year he went to Rome, where he remained until $\mathrm{I} 874$.

\section{A 26}

102

Cupid Begging his Arrows.

Canvas, $25 \times 30$.

Signed on front, Gray, I844. Engraved by John Sartain for The Diadem, 1846. Carey Collection.

\section{Clifford Prevost Grayson.}

Born in Philadelphia, July 14, 1857. Studied in P. A. F. A.; with Gérôme and Léon Bonnat, and in the École des Beaux-Arts, Paris. Grand Prize American Art Association, New York, I886. Temple Gold Medal, P. A. F. A., I887.

\section{A 27}

Fisherman's Family.

Signed on front, Clifford P. Grayson, Concarneau. Paris Salon, I885. Temple Gold Medal, P. A. F. A., I887. Purchased by Temple Fund, 1887 . 


\section{Philip B. Hahs.}

Born in Reading, Pa., August 4, I853; died in Philadelphia, August 27, 1882. Received his education at P. A. F. A., entering in 1876 with the first class in the present building.

$\begin{array}{lrr}\text { A } 28 & \text { Library } \\ \text { Study of an Old Man. } & & \text { Canvas, } 12 \times 16 .\end{array}$

Three-quarter length, seated, facing right. Portrait of John Berthellot, a favorite model with Philadelphia painters. Signed on front, Philip B. Hahs, I 882.

Presented by Mrs. Charles S. Hahs, I 884.

\section{John McLure Hamilton.}

Born in Philadelphia, January 3I, I853. Studied at P. A. F. A., at Antwerp, and at the École des Beaux-Arts. Honorable Mention, Paris Salon, IS92. Portrait of Mr. Gladstone at Hawarden purchased by the French Government for the Luxembourg. Member Society Pastellists and Society Portrait Painters, London. Member Society American Artists.

\section{A 29}

\section{The Right Hon. William Ewart Gladstone}
at Downing Street.
Canvas, $31 \times 35$.

Signed on front, J. McLure Hamilton, Downing Street, i 893. Purchased by the Gilpin Fund from Sixty-Third Annual Exhibition, P. A. F. A., I 894 .

\section{James Hamilton, P.A.}

Born near Belfast, Ireland, October I, I819; died in Philadelphia, March Io, I 878 . Taught drawing in this city as a means of support while studying art. Went to England in 1854 and remained two years, chiefly studying the works of Turner.

Old Ironsides.

A 30

Signed on front and back, J. Hamilton, 1863.

Presented by Mrs. C. G. Taitt, I 885 . 
A 31

84

The Ancient Mariner.

Signed on front, Jas. Hamilton. Suggested by Coleridge's Poem.

Loaned by Edward H. Coates.

\section{Alexander Harrison.}

Born in Philadelphia, January $\mathbf{1 7}$, 1853 . Studied in P. A. F. A., and the École des Beaux-Arts, Paris. Member Société Nationale des Beaux-Arts, Paris. Member Society of American Artists, New York. Member Royal Institute of Painters in Oil Colors, London. Corresponding Member Society of Secessionists, Berlin and Munich. Member Cercle de l'Union Artistique, Paris. Honorable Mention, Paris Salon, I885; Temple Medal, P. A. F. A., r887; Gold Medal, International Exposition, Paris, I889; also made Chevalier of the Legion of Honor and Officer of Public Instruction by the French Government; Second Medal, Munich Salon, I89I; Medal of Honor, Brussels and Ghent, 1892 ; P. A. F. A. Gold Medal of Honor, I894.

A 32

The Wave.
$6 I$

Canvas, $40 \times 1 \mathrm{r} 9$.

Signed on front, Alex. Harrison. Purchased by Temple Fund, I 89 I.

\section{William Keesey Hewitt, P.A.}

Born in Philadelphia, February I4, I8I7; died January 13, 1893. Began his art experience as a lithographer in New York. Returned to Philadelphia in $\mathrm{I} 84 \mathrm{I}$ and took up portrait painting in $\mathrm{I} 843$. An exhibitor in P. A. F. A. since 1847 .

A 33
Portrait of Jonathan Rubicam.

Bust, facing front. A citizen of Philadelphia. Signed on back, W. K. Hewett, I 855 .

Presented by Mrs. C. A. Rubicam, 1877.

\section{Thomas Hicks, N.A.}

Born in Newtown, Bucks Co., Pa., October 18, 1823; died 189o. Began portrait painting at fifteen. Studied in P. A.F. A., N. A., and in London, 
Paris, Florence, and Rome. Returned to New York, IS49, and began a successful career as a portrait painter. President Artists' Fund Society of New York, r873-1885.

\author{
A $34 \quad 108$ \\ Portrait of General George \\ Gordon Meade. \\ Canvas, $59 \times 95$. \\ Loaned by Col. George Meade.
}

\title{
Thomas Hill.
}

Born in Birmingham, England, September I I, I829. Brought to America in I840, and subsequently took up ornamental painting in Boston. Remored to Philadelphia in 1853 , where he was employed decorating cottage furniture. Entered the life class of the P. A. F. A., under Rothermel, in 1854. Took a six months' course in the studio of Paul Meyerheim, Paris, in I866. Went to San Francisco in 1867. First Medal, Maryland Institute, I853; First Prize, Art Union of San Francisco, I865; First Medal for Landscape, Centennial Exhibition, 1876; Medal, Palette Club, New lork; Temple Medal, P. A.F.A., I884.
A 35
83

Yosemite Valley. General View
from Bridal Veil Meadow.
Canvas, $72 \times 96$.

Signed on front, T. Hill.

Presented by William B. Bement, I 885 .

\section{Lucy Dennis Holme.}

Born in Salem Co., N.J., June 23, I848. Studied at P. A. F. A., also with William Sartain, and for two years at the Colorossi Academy, Paris, with Courtois and Rixens. Awarded Mary Smith Prize, P. A. F. A., ISS4. Honorable Mention, P. A. F. A., I 886.

\section{A 36}

Petrona.

Signed on front, L. D. Holme. Mary Smith Prize, P. A. F. A. Purchased by Temple Fund, 1884 . 


\section{Winslow Homer, N.A.}

Born in Boston, Mass., February 24, 1836 . Member American Water-Color

Society. Medal, World's Columbian Exposition, I893.

A $37 \quad 60$ Canvas, $3^{8} \times 68$.

Fox Hunt.

Signed on front, Homer, 1893. Purchased by Temple
Fund, I 894 . Fund, I 894 .

\section{Daniel Huntington, P.N.A.}

Born in New York, October 14, 1816, where he still lives. Studied with S. F. B. Morse, and with Ferrero in Rome in 1839 and 1844 . President of the N. A. D. for twenty-five years, resigned in 1890 . President of the Century Club, New York, since 1879. Received degree of LL.D. from Hamilton College.

\section{A 38}

Mercy's Dream.

Signed on front, D. Huntington, I84I. Engraved by John Cheney for The Gift, 1843. Smaller replica in the Corcoran Gallery. Mezzotinted by A. H. Ritchie. Carey Collection.

\section{A 39}

Christiana and her Family passing through the Valley of the Shadow of Death. Canvas, $72 \times 92$.

Engraved by John Sartain for The Diadem, I 845. Carey Collection.

\section{A 40} 97

Florentine Girl.

Engraved by John Cheney for The Gift, i 843. Carey Collection.

\section{Henry Inman, N.A.}

Born in Utica, N.Y., October 20, I801 ; died in New York, January 17, 1846. Studied with J. W. Jarvis. One of the founders of the N. A. D., and its first 
Vice-President. Settled in Philadelphia, 1832 , where he was engaged in the early introduction of lithography. Director P. A. F. A., I834-36. Visited Europe in 1845 . Painted portraits of Macaulay, Chalmers, and Wordsworth, on commissions from this country.

A 4 I

Portrait of Thomas Babington Macaulay.

Canvas, $24 \times 30$.

Bust, facing left. Painted upon order of Mr. Edward L. Carey. The likeness endorsed by Lord Macaulay in a letter to the owner. Engraved by John Sartain. Carey Collection.

\section{A 42}

83

Portrait of Thomas Sully.

Mill-board, $20 \times 24$.

Bust, facing left. Painted in I 844. Unfinished.

Presented by Miss Blanche Sully, 1891.

\section{A 43}

Lady with a Mask.

Canvas, $25 \times 30$.

Signed on front, H. Inman, and on back, H. Inman, Pinxt., 1841. Engraved by John Sartain for The Diadem, I846. Carey Collection.

\section{A 44}

88

Mumble-the-Peg.

Canvas, $20 \times 24$.

Signed on front, Inman, I 842. Engraved by Joseph Ives Pease for The Gift, I844. Carey Collection.

\section{A 45}

Portrait of the Artist.

Canvas, $10 \times 12$.

Bust, facing right, with hat on. Signed on back, Sketch by H. Inman of himself at 33, June, I 834.

Bequeathed by Cephas G. Childs, I87I.

\section{A $46 \quad$ Board Room}

Portrait of Caleb Cope.

Canvas, $28 \times 36$.

Bust, facing left. Seventh President of the P. A. F. A., I 859-I 87 I. 


\section{Frank Le Brun Kirkpatrick.}

Born in Philadelphia, August 19, 1853. Studied at the Royal Bavarian Academy, Munich, 1876 to 1880 , with Professors Strachuber, Barth, and Seitz, and awarded Medal of the First Class. Visited the chief art centres of Europe. Instructor in Composition, P. A. F. A., I89o.

\section{A 47}

In the Museum.

Signed on front, F. L. Kirkpatrick, 1883. Purchased by Temple Fund, I 884.

\section{Anna Elizabeth Klumpke.}

Born in San Francisco, Cal., August 22, I856. Pupil of T. Robert Fleury, Bouguereau, and de Vuillefroy. Studied at the Julian School, Paris, where she won the first grand prize over 150 pupils. Honorable Mention, Paris Salon, 1885; Bronze Medal, Universal Exposition, Paris, 1889; Silver Medal, Versailles, 1889; Temple Gold Medal, P. A. F. A., 1889.

\section{A 48}

In the Wash-House.

Signed on front, A. E. Klumpke, Paris, 1888. Paris Salon, I 888; Temple Gold Medal, I889.

Presented by the Artist, I 890 .

\section{Daniel Ridgway Knight, P.A.}

Born in Philadelphia, I845. Studied in P. A. F. A., and began painting in Philadelphia. Pupil of Gleyre, in Paris, 1872 , and Meissonier, 1876 . Honorable Mention, Paris Salon, 1884; Medal Third Class, Paris Salon, I888; Medal, Second Class, Munich Exhibition, I888; Chevalier Legion of Honor, I889; Medal, World's Columbian Exposition, I893; Cross of Knight Royal Order of St. Michael of Bavaria, Munich Exhibition, I893; P. A. F. A. Gold Medal of Honor, 1894. Studio in Poissy. 


\section{A 49}

$8 I$

Hailing the Ferry.

Canvas, $64 \times 83$.

Signed on front, Ridgway Knight, Paris, i 888. Paris Salon, I888. Second Gold Medal, Munich, I888; Silver Medal, Universal Exposition, Paris, I889.

Presented by John H. Converse, I8gI.

\section{Robert Koehler.}

Born in Hamburg, Germany, November 28, 1850 . Taken to Milwaukee, IVis., when a child. Apprenticed to a lithographer in Pittsburgh, I866. Followed his trade in Pittsburgh and New York, studying at N. A. D. Pupil of Defregger in Munich, 1873, and Art Students' League, New York, till '1879; again at Munich till 1886. First exhibited at N. A. D., I877. Mention Honorable, Universal Exhibition, $\mathrm{I} 883$ and I888; Cross of St. Michael from Bavarian Government. Returned to New York, I892. Now director Minneapolis School of Fine Arts.

\section{A Holy-Day Occupation. \\ A 50 \\ 62}

Signed on front, Rob. Koehler, Munich, i881. Reproduced in Academy Album.

Presented by Joseph E. Temple, i 882.

\section{John Lewis Krimmell.}

Born in Edingen, Würtemberg, Germany, 1787 ; drowned at Germantown, Philadelphia, July I5, I821. Came to Philadelphia in I8Io.

\section{A 5 I}

102

A Wedding. Bishop White Officiating.

Presented by Paul Beck, i 842 .

\section{A 52}

102

Fourth of July in Centre Square.

Canvas, $23 \times 29$.

The old Water-Works of Philadelphia, on the present site of the Municipal Building, at Broad and Market Streets. Exhibited, P. A. F. A., I8 I2. Purchased at the Paul Beck sale, 1845 . Reproduced in Academy Album. 


\section{James Read Lambdin.}

Born in Pittsburgh, Pa., May ro, $\mathbf{r} 807$; died in Philadelphia, January $3 \mathrm{I}$, 1889. Studied with Sully, I823-5. Removed to Kentucky. Returned and settled in Philadelphia as a portrait painter, 1838. Director of the P.A.F.A., I $846-64$.

\section{A 53}

54

Portrait of the Artist.

Half length, standing, facing front, with palette and maulstick in hand. Signed on front, J. R. L.

Presented by Alfred C. Lambdin, M.D., I89 I.

\section{John Smith-Lewis.}

Born in Burlington, N.J., I845. Studied in Paris, where he now lives. Honorable Mention, Paris Salon, 1886.

\section{A 54}

IO

\section{Waiting for Low Tide to Gather}

Sea-Weed; Coast of Brittany. Canvas, $96 \times 153$.

Signed on front, Smith-Lewis, I886. Honorable Mention, Salon, 1886.

Presented by the Artist, I 890.

\section{Charles Linford.}

Born in Pittsburgh, Pa., October II, I846. Medal, Boston, 1878. Honorary Member Pittsburgh Art Society.

\section{A 55}

Lowland Woods-Morning.

Signed on front, C. Linford, I 889. Purchased by Temple Fund, r 889 . 


\section{Edward Harrison May, A.N.A.}

Born in England in 1824 ; died in Paris, May 17,1887 . Came to this country when a child. Pupil of Huntington in New York. Went to Paris and studied with Couture, I85I. Life passed chiefly abroad.

\section{Dying Brigand.}

\section{A 56}

Signed on front, May, i 855 . Gold Medal at the Paris Salon of I 855 . Brought to this country and exhibited next year. Reproduced in Academy Album.

\section{George Willoughby Maynard, N.A.}

Born in Washington, D.C., March 5, I843. Studied in the Royal Academy of Fine Arts, Antwerp, I869-73. Nember Society American Artists, New York. First award of the Temple Gold Medal, P. A. F. A., I884; Gold Medal of Honor, American Art Association, New York, I888; Medal as one of the designers of World's Columbian Exposition, October 2I, I892. Member of International Jury of Awards, World's Columbian Exposition, I 893.

\section{Sappho. \\ A 57 \\ 63 \\ Canvas, $20 \times 24$. \\ Signed on front, Maynard. Awarded Gold Medal of Honor, American Art Association, New York, i 888. Purchased by Temple Fund, I889.}

\section{Henry Mosler.}

Born in New York, June 6, 1841. Removed to Ohio when a child, and at fourteen was employed as a draughtsman on a comic newspaper in Cincinnati, called Omnibus. Became a pupil of James H. Beard, I859. Went to Europe, I 863, studying in Düsseldorf and Paris. His painting, Le Retour, exhibited in Salon, I879, purchased by the French Gorernment for the Luxembourg. The Wedding Morning, Salon, I883, purchased for Museum of Fine Arts at Sydney, N.S.W. Medal, International Exhibition, Nice, I884; One of four prizes offered by American Art Association, $188_{5}$; Legion of Honor, grade of Chevalier, July, I892; Gold Medal, Vienna Art Exhibition, IS93. Returned to the United States, I866, remaining eight years. Has since lived abroad. 


\title{
A $5^{8}$
}

62

The Rainy Day.

Signed on front, Henry Mosler, Paris.

Canvas, $29 \times 36$.

\section{William Sidney Mount, N.A.}

Born in Sautucket, L.I., November 26, ISo7; died November I9, I868. Familiarly called the Wilkie of America.

\author{
A 59 \\ The Painter's Triumph. \\ Panel, $20 \times 24$. \\ Signed on front, W. S. Mount, I 838 . Engraved by Alexander- \\ Lawson for The Gift, I 840 . Carey Collection.
}

\section{John Neagle, P.A.}

Born in Boston, November 4, 1796 , during a temporary visit of his parents, who were Philadelphians; died in Philadelphia, September I 7, I865. Received instruction from Bass Otis and Stuart. Married a step-daughter and niece of Sully, and devoted himself to portrait painting. Director of the P. A. F. A., I830-3I.

Portrait of Pat Lyon.

A 60

Full length, facing front, at his forge. Born in England, - I779; came to Philadelphia, I793, where he died, April I5, I 829. Was an ingenious blacksmith and a local celebrity. Signed on front, John Neagle, Pinxt, 1829. Replica. This picture has been engraved by Thomas Kelly as The Village Blacksmith. Reproduced in Academy Album.

Presented by the Neagle Family.

\section{Burr H. Nicholls.}

Born in Lockport, N.Y. Studied with L. G. Sellstedt, Buffalo, and CarolusDuran, Paris. First exhibited at the Dudley Gallery, London, I879. 
A 61

59

Sunlight Effect.

Canvas, $42 \times 51$.

Signed on front, Burr H. Nicholls, I88I-2. Paris Salon, 1882.

Presented by Joseph E. Temple, I 883.

\section{Bass Otis.}

Born in New England, I784; died in Philadelphia, November 3, I86I. Invented the Perspective Protractor, I 8 I5, and made the first lithograph on stone produced in America, I8I9.

\section{A 62}

I9

Interior of an Iron Foundry.

Canvas, $51 \times 80$.

The only known composition by this portrait painter. First exhibited in the P. A. F. A., 18 I9.

Presented by the Artist.

\section{William Page, N.A.}

Born in Albany, N.Y., January 23, I8I I d died, Long Island, September 30, I885. Studied with S. F. B. Morse. Painted in Albany, New York, Boston, and Rome, Italy. Produced his famous Venus, $\mathbf{I} 859$, and Shakespeare from the Death Mask, i876.
A 63
I6

The Young Merchants.

Canvas, $36 \times 42$.

Engraved by Joseph Ives Pease for The Gift, I844. Carey

Collection.

\section{Charles Willson Peale, P.A.}

Born in Chestertown, Md., April I5, I74I ; died in Philadelphia, February 22, 1827. Began life as a saddler. Pursued portrait painting without regular instruction until 1768 . Then went to England and resided in the household of West. Returned to this country in 1770 . Painted at Mount Vernon the 
first and earliest authentic portrait of Washington, May, I772. He is said to have painted Washington from life fourteen times. Was one of the founders of the P. A. F. A. in 1805 , and a Director until 1810 .

\section{A 64}

Portrait of Robert Morris.

Canvas, $40 \times 50$.

Three-quarter length, seated, facing front. A signer of the Declaration of Independence, and the financier of the American Revolution.

Portrait of the Artist.

\section{A 65}

89

Bust, facing front, palette and brush in hand. Engraved by James B. Longaçre.

\section{A 66}

Portrait of the Artist in his Museum.

Canvas, $78 \times 103$.

Peale's Museum was established in the artist's residence, at Third and Lombard Streets, Philadelphia, in 1784 , and was transferred to the American Philosophical Society building, I 794 ; the State House, I 802 ; the Arcade, I 828 ; the Chinese Museum, I838; and the Masonic Hall, I844. Painted in I 824 and exhibited in P. A. F. A. same year. Reproduced in Academy Album. Presented by Mrs. Joseph Harrison, I 878 .

\section{A $67 \quad$ Board Room \\ Portrait of George Clymer. \\ Canvas, $22 \times 27$.}

Bust, facing right. First President of P. A. F. A., I 805 to I 8 I 3 .

\section{Raphaelle Peale.}

Born February I7, I774; died February 23, I825. Son of Charles Willson Peale. In company with his father, brother, and uncle, sketched Washington from life in 1795 .

$\begin{array}{lrr} & \text { A } 68 & 97 \\ \text { Fox-Grapes and Peaches. } & & \text { Panel, ro x I2. }\end{array}$

Signed on front, Raphaelle Peale, August 5, I8I 5.

\section{A 69}

Apples and Fox-Grapes.

Signed on front, Raphaelle Peale, Philadelphia, September 7, I 8 I 5 . 


\section{Rembrandt Peale, P.A., N.A.}

Born in Bucks Co., Pa., February 22, 1778 ; died in Philadelphia, October 3, 1860. Second son of Charles Villson Peale. Studied with his father, and with West, in London, and subsequently in Paris. Painted Washington from life, 1795. Produced his well-known composite portrait of Washington in 1823. Director of the P. A. F. A., I 8 II-I3.

\section{A 70}

90

Portrait of Jacques Louis David.

Canvas, $24 \times 30$.

Bust, facing right. Celebrated French artist. See page 55.

\section{A 7 I}

.90

Portrait of Dominique Vivant Denon.

Canvas, $24 \times 30$.

Bust, seated, facing left. French artist and author. Born in 1747 ; died in 1825 . Accompanied Bonaparte to Egypt, I788, and subsequently published his great work upon Egypt.

\section{A 72}

90

Portrait of Jean Antoine Houdon.

Canvas, $24 \times 29$.

Bust, facing right. Eminent French sculptor. Etched by

A. Rosenthal, Philadelphia. See page 90.

\section{A 73}

89

Portrait of the Artist.

Canvas, $17 \times 21$.

Head, with spectacles, facing right.

Presented by Mrs. Rembrandt Peale, i 869.

\section{A 74}

Print Room

Portrait of Richard Peters, of Belmont.

Panel, $7 \times 9$.

Bust, facing right. Nember of the Continental Congress; Judge U. S. District Court for Pennsylvania, I 792-I 828.

Presented by Mr. and Mrs. John W. Field, I 887.

\section{Charles Sprague Pearce.}

Born in Boston, October $\mathrm{I}_{3}$, I85 I. Studied with Bonnat, in Paris. Has resided chiefly abroad. Member Society of American Artists. Awarded Prize, $\$ 300$, P. A. F.A., IS8I ; Honorable Mention, Paris, ISSI; Gold Medal, 
Third Class, Paris, $188_{3}$; Gold Medal, Boston, 1884; Temple Gold Medal, P. A. F. A., I885; Gold Medal, Second Class, Munich, Bavaria, I888; Hors Concours, Paris, I889; Grand Diploma, Berlin, I89I ; Hors Concours, World's Columbian Exposition, I893; Chevalier of the Legion of Honor, France, I894.

\section{A 75}

Fantasie.

Signed on front, Charles Sprague Pearce, Paris.

Presented by Joseph E. Temple, I 884.

\section{William L. Picknell, A.N.A.}

Born in Boston, October 23, 1854. Studied with Inness, in Rome; with Gérôme, in Paris; and later with Robert Wylie, in Brittany, until that artist's death. Member Society American Artists, New York, and Society British Artists, London. Honorable Mention, Paris Salon, I880; Silver Medal, Boston, I88I ; Gold Medal, Boston, I884; Medal, World's Columbian Exposition, I 893 .

$$
\text { A } 76 \quad 62
$$

On the Borders of the Marsh.

Canvas, $60 \times 79$.

Signed on front, Wm. L. Picknell, I880. Paris Salon, I88 I. Reproduced in Academy Album.

Presented by Joseph E. Temple, I 88 I.

\section{Matthew Pratt.}

Born in Philadelphia, September 23, I734; died in Philadelphia, Janụary 9,

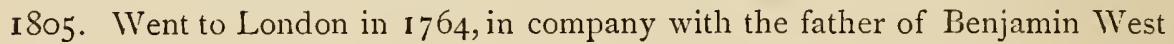
and with West's future wife, Miss Betsy Shewell, and took part in West's wedding. Became a pupil of West. Returned to Philadelphia in I768, and resumed his profession there.

$$
\text { A } 77 \quad 87
$$

Portrait of Benjamin West.

Canvas, $25 \times 30$.

Bust, facing right. See page 42.

Presented by Mrs. Rosalie V. Tiers Jackson, I 892. 


\section{A 78}

Portrait of Mrs. Benjamin West.

Canvas, $25 \times 30$.

Bust, facing left. Maiden name, Betsy Shewell, native of Philadelphia. Betrothed to Benjamin West before his departure for Europe in 1760 , and married to him in London, September 2, I 764 .

Presented by Mrs. Rosalie V. Tiers Jackson, I 892.

\section{Thomas Buchanan Read.}

Born in Chester Co., Pa., March I2, I822; died in New York, May II, 1872. Poet, painter, and sculptor. Worked in Philadelphia, New York, Cincinnati, Rome, and Florence.

Sheridan's Ride.

A 79

104 Canvas, $108 \times 142$.

Signed on front, Thomas Buchanan Read, Rome, I869. Illustrating the poem by Read.

Presented by the Children of Alfred D. Jessup, I88I.

\section{William Trost Richards, P.A., N.A.}

Born in Philadelphia, November I4, I8 33 . Went to Europe in 1855 , studying in Florence, Paris, and Düsseldorf. Opened studio in Philadelphia, 1856. Medal, Centemnial Exposition, I876; Bronze Medal, Paris Exposition, I889; Member American Water-Color Society, New York; Honorary Nember N. A. D.; Temple Medal, P. A. F. A., I885.

The Bell-Buoy, Newport, R.I.

A 80

Signed on front, Wm. T. Richards, I89I. Reproduced in Academy Album. Purchased by Temple Fund, I \$9I.

\section{Peter Frederic Rothermel, P.A.}

Born in Nescopec, Luzerne Co., Pa., July S, ISı7. Lives at Linfield, Montgomery Co., Pa. Received instruction from Bass Otis. Settled in Philadelphia 
as a portrait painter, $\mathbf{1} 840$. Went to Europe for study in $\mathbf{1} 856$. Director of the P.A. F. A., I 847-I855. Honorary Member N. A. D.; Honorary Member The Art Club, Philadelphia.
A $8 \mathrm{I}$
82

Paul at Ephesus.

Canvas, $64 \times 79$.

Signed on front, P. F. Rothermel, I872.

Presented by Mrs. Matthew Baird, I 887.

\section{John Singer Sargent, A.N.A., A.R.A.}

Born in Florence, Italy, of American parents, I 856. Studied with CarolusDuran. Member of Society American Artists; Member of Sociéte Nationale des Beaux-Arts, France; Associate Royal Academy of Arts, London; Honorable Mention, Paris Salon, I878; Second-Class Medal, Paris Salon, I88I ; Medal of Honor, Universal Exposition, Paris, I889; Legion of Honor, I889; Medal, Wrorld's Columbian Exposition, I893; Temple Gold Medal, P. A. F. A., I894.

\section{A 82}

Portrait of Mr. and Mrs. John W. Field.

\section{Print Room}

Canvas, $32 \times 44$.

Signed on front, John S. Sargent, Paris, 1882.

Presented by Mrs. John W. Field, I89I.

\section{Prosper L. Senat.}

Born in Germantown, Pa., I852. Studied at South Kensington Museum, London; and subsequently in Paris with Bonnat, passing his summers in Brittany and Antwerp.

\section{A 83 \\ 64}

Close of Stormy Day, Annisquam, Cape Ann. Canvas, 30 x 56.

Signed on front, Prosper L. Senat,-82.

Presented by Joseph E. Temple, r 883 .

\section{Joshua Shaw.}

Born in Billingbroke, Lincolnshire, England, 1777 ; died in Burlington, N.J., September 8, I860. Studied in England. Came to this country in I8I7, 
bringing with him West's picture of Christ Healing the Sick. W'as a celebrated inventor, his improvement in gunlocks being adopted by the United States Government.
A 84
IOI

Landscape.

Canvas, I 5 X 2 I.

Carey Collection.
A 85
IOI

Landscape.

Canvas, I5 $\times 2$ I.

Carey Collection.

\section{Mary Smith, A.P.A.}

Born in Philadelphia, September 25, I842; died June 6, I 878 . Daughter of Russell Smith, who founded in her memory the Mary Smith Prize of $\$ 100$, to be awarded to the resident woman artist producing the best picture at each Annual Exhibition of the P. A. F. A.

\section{Picking Cherries.}

\section{A 86}

Signed on back, Mary Smith, 1872.

Presented by Russell Smith, i 878 .

\section{Russell Smith, P.A.}

Born in Glasgow, Scotland, April 26, I812. Brought to America at an early age. Studied with James R. Lambdin in Pittsburgh. Came to Philadelphia, as a scene-painter, I 834 . Studied in London, Paris, and Rome, I $\$_{5} 0$ to 1852.

\section{A 87}

Chew House, Germantown.

Signed on front, Russell Smith, I 843.

\section{A 88}

20

Cocealamus Creek.

Signed on front, Russell Smith, i 846-76.

Presented by the Artist.
102

Panel, $17 \times 24$. 


\section{Xanthus Smith, A.P.A.}

Born in Philadelphia, February 26, 1839. Studied with his parents, both artists, and at P.A.F.A. Served on the staff of Admiral Dupont, in the U.S. Navy, during the War of the Rebellion.

\section{A 89}

Attack on Fort Fisher.

Signed on front, Xanthus Smith, I873.

Presented by Mrs. Joseph Harrison, 1878.

\section{Gilbert Stuart, P.A.}

Born in Narragansett, R.I., December 3, I755; died in Boston, July 27, 1828 . The acknowledged master of portrait painting in America. Went to England, I775, where he received instruction from West. Remained abroad until 1792, and painted some of his best pictures there. Upon his return lived in New York two years, when he came to Philadelphia to paint Washington. Remained until I805, and, after a brief sojourn in the District of Columbia, settled in Boston. There are about eight hundred known portraits by him.

\section{A 90}

Portrait of Mrs. Samuel Blodgett.

Canvas, $22 \times 28$.

Unfinished head, with turban, facing left. A daughter of Provost Smith, and a noted beauty and belle. Engraved by John Cheney for The Gift, i 845 . Carey Collection.

\section{A 91}

Print Room

Portrait of Same and Daughter.

Canvas, $22 \times 20$.

Unfinished heads, cut out of larger canvas.

Deposited by 'The Artists' Fund Society, of Philadelphia.

\section{A 92}

Portrait of Sir Henry Lorraine Baker.

Panel, $21 \times 26$.

Bust to right, facing front. Painted in 1817 . Admiral in the British Navy. Was with Admiral Cockburn in I814, when the British fleet came up the Chesapeake. 


\section{A 93}

89

Portrait of Elizabeth Bordley.

Canvas, $22 \times 28$.

Half length, standing, face left. Daughter of John Beale Bordley, of Maryland, and wife of James Gibson, of Philadelphia, a lawyer, and one of the founders of the P.A.F.A. Reproduced in Academy Album.

Bequeathed by her niece, Miss Elizabeth Mifflin, i 886.

Portrait of Samuel Griffin.

A 94

89

Bust, seated, facing left. Colonel in the Army of the Revolution. Member of Congress, 1789 , from Virginia. Died in New York and buried in Trinity Churchyard.

Deposited by his grandson, Dr. Ferdinand C. Stewart.

\section{A 95}

Portrait of Mrs. Samuel Gatliff and Daughter.

Canvas, $24 \times 30$.

Half length, seated, facing left, with child on lap. Daughter of Samuel Griffin, afterwards Mirs. Stewart.

Deposited by her son, Dr. Ferdinand C. Stewart.

\section{A 96}

89

Portrait of Samuel Gatliff.

Canvas, $24 \times 30$.

Half length, facing right. An English gentleman who settled in this country.

Deposited by Dr. Ferdinand C. Stewart.

\section{A 97}

89

Portrait of James Greenleaf.

Canvas, $25 \times 30$.

Bust, facing left. Painted in 1795 . One of the founders, with Robert Morris and John Nicholson, of the famous North American Land Company, 1795.

Deposited by J. R. Ritter.

\section{A 98}

89

Portrait of Mrs. William Jackson.

Canvas, $25 \times 30$.

Half length, seated, facing right. Daughter of Thomas Willing, and wife of Major Jackson, Private Secretary to Washington. Engraved for Griswold's Republican Court.

Bequeathed by her daughter, Miss Ann Willing Jackson, I 876. 
Portrait of John Nixon.

Canvas, $24 \times 29$.

Bust front, facing left. Prominent citizen of Philadelphia. Colonel in the Army of the Revolution. Read the Declaration of Independence to the people, July 8, I776. Etched by H. B. Hall, I 877 .

Bequeathed by his grandson, Henry Cramond, I 887.

A 100

89

Portrait of Mrs. Richard Peters, Jr.

Canvas, $24 \times 29$.

Half length, seated, facing left. Daughter of Thomas Willing, and wife of Richard Peters, Jr., one of the founders of the P. A. F. A.

Presented by her daughter, Mrs. John W. Field, I 887.

\section{A IOI}

Portrait of George Plumstead.

Canvas, $24 \times 28$.

Bust, facing right. A merchant of Philadelphia.

Bequeathed by his grand-daughter, Miss Helena R. Scheetz, I 89 I.

\section{A 102}

Portrait of Mrs. George Plumstead.

Bust, seated, facing left. Painted in I8oo. Born Anna Helena Amelia Ross.

Bequeathed by her grand-daughter, Miss Helena R. Scheetz, I89I.

\section{A 103}

Portrait of Washington.

Canvas, $60 \times 96$.

Full length, standing, facing left. Known as the Lansdowne portrait. Signed on front, G. Stuart, I796. There is satisfactory evidence that this is the original, painted from life, and not a replica.

Received from Estate of William Bingham, i 8 I I.

Portrait of Washington.

\section{A 104}

Bust, facing left. Replica of Athenæum head, of which Stuart is known to have painted about fifty.

Bequeathed by Paul Beck, I 845 . 


\section{Robert Matthew Sully.}

Born in Petersburg, Va., July I7, 1803 ; died —. A son of Matthew Sully, elder brother of Thomas Sully, with whom he studied. Painted in England, I 824 to 1828 .
A 105

Portrait of James Northcote, R.A.

Canvas, $28 \times 3^{6}$.

Half length, seated, facing right. On back of canvas: James Northcote, R.A., in the 79th year of his age. Painted by R. M. Sully, London, August, I 825 .

Presented by the Artist, I 83 I.

\section{Thomas Sully, P.A.}

Born in Horncasstle, Lancashire, England, June 8, $178_{3}$; died in Philadelphia, November 5, I872. Studied with his brother Lawrence Sully and with Stuart. Settled in Philadelphia, 1809 . Devoted himself to portrait painting. Visited Europe and painted Queen Victoria from life in 1837 . In the IIistorical Portrait Exhibition at the P. A. F. A., I887-88, there were exhibited one hundred and six pictures by his hand, showing great versatility.

\section{A 106}

Portrait of George Frederick

Cooke as Richard III.

Canvas, $60 \times 94$.

Full length, facing right. English tragedian. Came to this country in 18 Io, and died in New York, isi2. Buried in St. Paul's Churchyard, New York. Signed on front with monogram, T. S., I8I I. Reproduced in Academy Album.

Presented by friends and admirers of the Actor.

\section{A 107}

Portrait of Gideon Fairman.

Panel, $8 \times$ ro.

Bust, facing right. An engraver who settled in Philadelphia, I 810 , and became associated with Joseph Perkins in steelplate engraving for bank notes.

Bequeathed by Cephas G. Childs, I 87 I . 
A 108

Portrait of Elizabeth Willing Jackson.

Canvas, $25 \times 30$.

Bust, facing right, seated. Daughter of Major and Mrs. William Jackson. See A 98.

Bequeathed by her sister, Miss Ann Willing Jackson.

\section{A rog}

Portrait of Charles Kemble.

Canvas, $25 \times 30$.

Bust, facing left, in hat and cloak. Brother of Mrs. Siddons and John Philip Kemble, and father of Frances Anne Kemble. See A I Io. Signed on front with monogram, T. S., I 833 .

Presented by Mrs. John Ford.

A Iro

Portrait of Frances Anne Kemble.

Canvas, $25 \times 30$.

Bust, facing right. An actress and authoress, popularly known as Fanny Kemble. Married to Pierce Butler, of Philadelphia. Signed on front with monogram, T. S., I833.

Presented by Mrs. John Ford.

\section{A III}

Portrait of Frances Anne Kemble.

Canvas, $25 \times 30$.

Bust, facing left. Signed on front with monogram, T. S., 1833. Engraved by John Cheney for The Gift, 1836. Carey Collection.

\section{A II2}

Portrait of Eliza Leslie.

Canvas, $28 \times 36$.

Bust, facing right, seated, holding portfolio lettered: Sketches. An American authoress, sister of Charles Robert Leslie, R.A. Signed on back with monogram, T. S., 1844. Engraved by John Cheney for Godey's Lady's Book, 1846.

\section{A II3}

Portrait of John McLean.

Panel, i 7 x I9.

Head, facing right. Postmaster-General of the United States, I 823, and Associate Justice Supreme Court of the United States, I 829 to I861. Signed on front with monogram, T. S., I83I. Lithographed by Albert Newsam. 


\section{A II4}

Portrait of James Ross.

Canvas, $40 \times 50$.

Three-quarter length, standing, facing front. Painted in I 8I4. Distinguished lawyer and United States Senator from Pennsylvania, I794 to I803. Engraved by Goodman and Piggot.

\section{A II5}

Isabella, in Measure for Measure.

Canvas, $28 \times 36$.

Bust, standing. Signed on back with monogram, T. S., I836. Engraved by John Cheney for The Gift, I840. Carey Collection.

\section{A II6 Print Room}

Portrait of Miss Eliza W. S. Peters. Canvas, $32 \times 44$.

Bequeathed by John W. Field, I887.

\section{A II7 Board Room}

Portrait of Edward L. Carey.

Canvas, $25 \times 30$.

Bust, facing front. Nonogram, T. S., on back. Fourth President P. A. F. A., I 845 .

\section{Henry Thomas.}

Nothing is known of this artist but that he was a pupil of John Neagle.

\section{A 118}

Portrait of Junius Brutus Booth as Richard III. Canvas, $40 \times 52$. Three-quarter length, facing left. The father of Edwin Booth. An eminent tragedian, particularly successful as Richard III. Signed on back of canvas, H. Thomas, I83I. Presented by relatives of the Artist.

\section{Frank Henry Tompkins.}

Born in Hector, N. Y., May I3, I847. Studied at Art Students' League, N.Y., and with Professors Gisys and von Loefftz, Royal Academy, Munich. Received two Silver Medals, the highest given in the technical classes at Munich, and Gold Medal from the Charitable Mechanics' Association, Boston. 


\section{A II9}

The Penitent.

Canvas, $24 \times 28$.

Half-figure, seated, profile, facing left. Signed on front,

F. H. Tompkins. Purchased by the Temple Fund, I 892.

\section{William Brooke Thomas Trego.}

Born in Yardley, Bucks Co., Pa., September 15, 1858. Studied with his father, and in 1879 entered the schools of the P. A. F. A., remaining three years. Studied in Paris at the Julian Academy, and under Bouguereau and Fleury, from 1887 to I890. First Toppan Prize, P. A. F. A., I882. Temple Medal Prize Exhibition, P. A. F. A., I883.

\section{A 120}

Battery of Light Artillery en Route.

Canvas, $31 \times 65$

Signed on front, W. T. Trego, Phila., I882. Toppan Prize, P. A. F. A. Reproduced in Academy Album.

Presented by Fairman Rogers, I 883.

\section{John Trumbull, P.A.}

Born in Lebanon, Conn., June 6, 1756 ; died in New York, November Io, I843. Served in the Revolutionary War and rose to the rank of colonel. Studied .under Copley, in Boston, and in England under West, I780 to 1789. Painted Washington from life several times. The Trumbull Gallery at Yale College, New Haven, contains his most important works.

A I2I

The Siege of Gibraltar.

The artist painted four replicas of this picture, all of different sizes. The present one was made for William Sharp, to engrave from, and has a key to the characters in the artist's autograph.

Deposited by Robert O'Neill Wickersham. 


\section{Albert Bernhard Uhle.}

Born in Saxony, October 15, 1847. Studied at P. A. F. A. and in Munich and Italy, I875 to 1877 . Instructor of the portrait classes in schools of P.A. F. A., 1888 to 1890. Studio in Philadelphia.

\section{A 122}

60

Portrait of Joseph E. Temple.

Canvas, $25 \times 30$.

Bust, facing right. Established the Temple Fund.P. A. F. A. See Introduction, page 5 .

Presented by Joseph E. Temple, I 886.

\section{A 123}

Study. Male Head.

Canvas, $18 \times 22$.

Signed on front, B. Uhle, I876. Painted in Munich.

Presented by the Artist, I 887 .

\section{A $124 \quad$ Board Room}

Portrait of George S. Pepper.

Canvas, $28 \times 34$.

Three-quarter length, facing left. Signed on front, B. Uhle, Pxt. Ninth President of the P.A. F. A. Died May 2, I89o.

Presented by the Executors of the late George S. Pepper, I 890 .

\section{John Vanderlyn, P.A.}

Born in Kingston, N.Y., October I5, I775; died September 24, 1852. Received instruction from Archibald Robertson and Gilbert Stuart. Spent much time abroad, $\mathbf{1} 796-1801$, and $\mathbf{1} 805-1815$. Painted there his most famous pictures : Marius amid the Ruins of Carthage, and Ariadne. His Landing of Columbus is one of the panels in the Capitol at Washington.

\section{A 125}

Ariadne of Naxos.

Signed on front, J. Vanderlyn, fect. Parisiis, i 8 I 4. The picture is recognized as the masterpiece of the artist, and was purchased from him by the celebrated artist and engraver A. B. Durand, in $183 \mathrm{I}$, the autograph receipts being in possession of the P.A.F.A. It was from this picture that 
Mr. Durand engraved his famous plate, admitted to be the best engraving ever made in this country, and the equal of any contemporary European work. Reproduced in Academy Album.

Presented by Mrs. Joseph Harrison, I 878.

\section{Denis A. Volozan, P.A.}

One of the first Academicians of the P. A. F. A., elected at a special meeting, March I3, I810; also a member of the Society of Artists of the United States, organized in Philadelphia in May, I8Io, and one of the professors in the first schools opened at the P. A. F. A. in 1812. Last exhibited at the Eighth Annual Exhibition, May, 1819.

\section{A 126}

Homer Reciting his Poem in the City of Argos. Canvas, $32 \times 42$. This picture was designed in Paris and finished there. First exhibited in the P. A. F. A. in $18 \mathrm{II}$.

\section{Robert William Vonnoh.}

Born in Hartford, Conn., September $\mathbf{1} 7$, 1858. Studied in Paris with Boulanger and Lefebvre, I88I. Returned in $\mathbf{I} 88_{3}$ and painted portraits, chiefly of children, at Boston. Instructor in the Museum of Fine Arts, Boston, until 1887. Went to France, and remained there, painting out of doors at Grez and elsewhere near Paris, until I89I, when he returned and became instructor of painting at the P. A. F. A Member Society American Artists. Medals at the Massachusetts Charitable Mechanics' Fair, Boston, I884; Honorable Mention, Paris Salon, 1889; Bronze Medal, Universal Exposition, Paris, 1889; Medal, World's Columbian Exposition, I893.

\section{A 127}

Companion of the Studio.

Canvas, $38 \times 50$.

Signed on front, Robt. W. Vonnoh, Paris, i 888. Paris Exposition, I889. Purchased by Temple Fund, i 892.

\section{A 128} 18

November.

Canvas, $3^{2} \times 4^{\circ}$.

Signed on front, R. W. Vonnoh, I8go. Purchased by Temple Fund, I894. 


\section{Ida Waugh, A.P.A.}

Born in Philadelphia. Daughter of Samuel B. Waugh, who was her first teacher. Studied at P. A. F. A. in I 888 ; and in Paris, 1889 , with Lefebvre and B. Constant, and in I89I-92 with George Callot and Paul Delance.

$\begin{array}{cr}\text { Hagar and Ishmael. } & 22 \\ \text { Signed on front, Ida Waugh, Paris, I } 889 . & \text { Canvas, } 48 \times 70 . \\ \text { Presented by Charles W. Whalon, I } 889 . & \text { Parton, I } 890 .\end{array}$

\section{Samuel B. Waugh, P.A.}

Born in Mercer, Pa., I8I4; died in Philadelphia, September I8, I 885. Studied in Philadelphia and abroad, where he painted a number of portraits of distinguished foreigners, among them Thorwaldsen, with whom he was on terms of friendship.

\section{A 130}

Portraits of the Cope Brothers.
85

Canvas, 36 x 29 .

Three heads, oval. Thomas P., Israel, and Jasper Cope, prominent merchants and shippers of Philadelphia. Signed on front, S. B. Waugh, 1853. Engraved by Samuel Sartain.

\section{A I3I}

88

\section{Portrait of Mrs. Henry D. Gilpin.}

Half length, seated.

Canvas, $30 \times 37$.

Presented by Mrs. Henry D. Gilpin, I 867.

$\begin{array}{lr}\text { A I32 } & \begin{array}{r}\text { Board Room } \\ \text { Canvas, } 30 \times x_{3} 6 .\end{array} \\ \text { Portrait of Henry D. Gilpin. } & \text { Sixth President of P. A. } \\ \text { F. A., I } 852 \text { to I } 859 . & \\ \text { Presented by Mrs. Henry D. Gilpin, I } 867 .\end{array}$

\section{Edwin Lord Weeks.}

Born in Boston. Studied with Bonnat and in the École des Beaux-Arts, Paris. Honorable Mention, Paris Salon, 1885 ; Medal, Paris Salon, ISS9; First Medal, Universal Exposition, Paris, I 889; Diploma of Honor, Universal Exposition, Berlin, 189I; Gold Medal, Philadelphia Art Club, I891. 
A 133

The Three Beggars of Cordova.

Canvas, $66 \times 98$.

Signed on fiont, E. L. Weeks. Paris Salon, I89ı. Gold

Medal, Philadelphia Art Club, i89 I.

Presented by Charles W. Wharton, I 892.

\section{Benjamin West, P.A., P.R.A.}

Born in Springfield, Chester Co., Pa., now embraced in Delaware Co., Octcber ro, 1738; died in London, England, May II, I820. Went to Europe, July, I760, and never returned to this country. Patronized by George III. from I767 to 1802 . Second President of Royal Academy, London, succeeding Sir Joshua Reynolds in $\mathbf{1 7 9 2 . ~ S e e ~ p o r t r a i t , ~ A ~ 7 7 , ~ p a g e ~} 28$.

\section{A 134}

Over Main

Stairway

\section{Death on the Pale Horse.}

Canvas, $177 \times 55$.

Signed on front, Benj. West, Octr. Io, I8I7. "No fancy could have better conceived and no pencil more happily embodied the visions of sublimity than his has in his inimitable picture from Revelation. Its subject is the opening of the seven seals, and a more sublime and awful picture I never beheld. It is impossible to conceive anything more horrible than Death on the white horse, and I am certain no painter has exceeded Mr. West in the fiery horror and despair which he has represented in the surrounding figures." -Washington Allston. Purchased in 1836.

\section{A 135}

Paul and Barnabas.

Canvas, $115 \times 147$.

\section{A 136}

Christ Rejected.

Canvas, $200 \times 264$.

Acknowledged to be the best work of this artist. Painted in his eightieth year. At the sale of his pictures, after his death, it brought 3000 guineas. Exhibited P. A. F. A., I 843. Engraved by John Sartain. Reproduced in Academy Album.

Presented by Mrs. Joseph Harrison, I 878. 


\section{Isaac L. Williams, P.A.}

Born in Philadelphia, $\mathbf{1 8} \mathbf{1} 7$, and lives in his native city. Studied with John Neagle, at P. A. F. A., and in Europe. Has alternated landscape and portrait painting since $\mathrm{I} 844$.
A $\mathbf{3} 37$
96

View in Dovedale, England.

Canvas, $24 \times 36$.

Signed on front, I. L. Williams, Paris, I 866.

\section{A 138}

83

Portrait of John Neagle, P.A.

Canvas, $22 \times 27$.

Bust, facing left. The eminent American artist. See page 24.

Presented by Garrett C. Neagle, 1894.

\section{William E. Winner, P.A.}

The following unsigned work is claimed for this artist by members of his family.
A $\mathbf{1 3 9}$
82

Portrait, Unknown.

Canvas, $25 \times 30$.

Head and bust of elderly gentleman; with thin gray hair and full florid face, turned to the right.

Presented by Charles Henry Hart, i 884.

\section{George Bacon Wood, A.P.A.}

Born in Philadelphia, January 6, 1832 . Studied in P. A. F. A. Has deroted much time to photography, and received many honors in that branch.

\section{A 140}

Interior of Library of Henry

C. Carey.

Canvas, $14 \times 20$.

Signed on front, G. B. Wood, 1879. Shows many pictures now in the Academy, upon the walls of Mr. Carey's library. Presented by the Artist, 1880 . 


\section{Joseph Wright.}

Born in Bordentown, N.J., July 16, 1756; died during the yellow fever epidemic in Philadelphia, 1793. His mother, Patience Lovell Wright, was famous as a modeller in wax. Studied in London with West and John Hoppner, who married his sister. Returned to this country in $\mathbf{1 7} 82$, and the next year painted a portrait of Washington, from life, at Rocky Hill, N.J. He subsequently had other sittings from Washington, and, in I790, obtained a profile likeness of him while in church, which he afterwards etched. $\mathrm{He}$ was appointed by Washington the first die-sinker in the United States Mint.

\section{A I4I}

Joseph Wright and Family.

Canvas, $32 \times 38$.

All full lengths; wife seated on left with child on her lap, small boy leaning on her knee, and little girl seated at her feet. The artist, with hat on, entering at right.

Presented by Edward S. Clarke, 1886.

\section{Robert Wylie, A.P.A.}

Born in the Isle of Man, 1839; died in Pont Aven, Brittany, February 13, I877. Studied at the P. A. F. A. Curator of the same from I859 to I863; elected Associate, 1862. Went to Paris, I865. Received a Medal of the Second Class at the Salon, 1872 .

\section{A 142}

The Story-Teller; Breton Interior.

Reproduced in Academy Album.

'Presented by Joseph E. Temple, I882. 


\section{BRITISH PICTURES}

\section{Henry John Boddington.}

Born in I8II; died in Barnes, April II, I865. Son of Edward Williams, of same place. Changed his name because so many of his family were artists. Member of the Society of British Painters. Exhibited at the Royal Academy.

B 200

Hayes Common; Storm Coming On.

Signed on front, H. J. Boddington. Carey Collection.
74

Panel, $8 \times \mathrm{r}_{3}$.

\section{Robert Barrett Browning.}

The son of Robert and Elizabeth Barrett Browning. Studied in Antwerp. Exhibited for the first time in England at the Royal Academy, I878.

\section{B 201}

The Delivery to the Secular Arm: Incident of the Spanish Inquisition in the Netherlands. Canvas, $90 \times 13 \mathrm{r}$.

Signed on front with monogram, R. B. B., I880.

Presented by Mrs. Bloomfield Moore, I 882.

\section{Alfred Edward Chalon, R.A.}

Born in Geneva, February $\mathbf{1 5}, \mathbf{1 7} 8 \mathbf{1}$; died in London, October 3, I860. Studied in the Royal Academy Schools. Elected Associate in I8I2, and Academician in $\mathbf{I} 8 \mathbf{1 6 .}$ Painter in Water-Colors to the Queen. 
B 202

Portrait of a Lady.
Print Room

Water-Color, II x I4.

Signed on front, A. E. Chalon, R. A., I836. Engraved by John Cheney for The Gift, i 839. Carey Collection.

\section{George Cole.}

Born in Portsmouth, I8Io. Received no instruction in art. Devoted himself for some years to animal painting in Portsmouth. Exhibited for the first time in London in 1840 . Elected a member of the Society of British Artists in I850, and Vice-President of same in 1878 .

Stable Interior.

B 203

Signed on front, George Cole, 1863.

Canvas, $\begin{array}{r}7 \text { I } \\ 48 \times 72 .\end{array}$

Presented by Thomas Mellor, i 882 .

\section{William Collins, R.A.}

Born in London, September I8, I788; died in same city, February 17, 1847 . Studied under his father and George Morland. Exhibited in the Royal Academy, I807, elected Associate in I8I4, Academician in I820. His work is much esteemed in England, and many of his pictures have been engraved in the Art Joumal and other publications.

\section{The Morning Lesson.}

B 204

Signed on front, W. Collins, i 836 . Carey Collection. Reproduced in Academy Album.

\section{Thomas Sidney Cooper, R.A.}

Born in Canterbury, I803. Began his professional career there as a scene painter about $\mathbf{1} 820$. Went to London in $\mathbf{1} 823$. Studied in the British Museum and Schools of the Royal Academy. Went to France in I827, and afterward to Brussels, where he remained several years with Verboeckhoven. Made an Associate in 1845 , Academician in 1867 . 
Cattle.

B 205

Signed, T. Sidney Cooper, I 844 . Carey Collection.
72

Canvas, $28 \times 38$.

\section{Charles Locke Eastlake, P.R.A.}

Born in Plymouth, November 17, I793; died in Pisa, December 24, I865. Received early instructions from Prout. Became a pupil in the Royal Academy Schools in I809. Went to Italy, Greece, and Sicily in I816; after a short visit to his native land, returned to Italy, where he remained for twelve years. First exhibited in the Royal Academy in 1823 . Elected an Associate in 1827 , an Academician in $\mathbf{1} 830$, and in 1850 elected President and knighted. Received the honorary degree of D.C.L. at Oxford, and was a Chevalier of the Legion of Honor.

\section{B 206}

Hagar and Ishmael in the Desert.
71

Canvas, $30 \times 38$

Signed on front, C. L. Eastlake, I 843 . Engraved by John

Sartain for The Diadem, I845. Carey Collection.

\section{William Gow Ferguson.}

Born in Scotland; died in London, about $\mathbf{1 6 9 5 . ~ S t u d i e d ~ i n ~ h i s ~ o w n ~ c o u n t r y ~}$ and passed some years on the Continent. Acquired reputation as a painter of dead game and still-life. Pictures in the Berlin Gallery and National Gallery of Scotland

Dead Game.

Dead Game.
69

Canvas, $17 \times 19$.

69

Signed on front, G. Ferguson, I674.

\section{John Hoppner, R.A.}

Born in Whitechapel, April 4, I758; died in London, January 23, I8Io. Was a choir-boy in one of the royal chapels, and the King made him an allowance. 
Entered the Schools of the Royal Academy, I775; became an Associate, 1793 , and Academician, 1795. Was portrait painter to the Prince of Wales, and a rival of Sir Thomas Lawrence.

\section{B 209}

Portrait of William Pitt.

Bust, facing right.
75

Canvas, oval, $20 \times 24$.

\section{Maria Anna Angelica Catharina Kaufmann, R.A.}

Born in Schwartzenburg, in the Bregenzer Wald, October 30, $\mathbf{1 7 4 1}$; died in Rome, November 5,1807 . Instructed by her father, who was a painter. Went to Florence in $\mathbf{1 7 5 7}$, to Rome in $\mathbf{I} 759$, and to Venice in $\mathbf{I} 764$; from there to England in 1765 . One of the original thirty-six members of the Royal Academy in 1768 . In 1782 she married Antonio Zucchi, a Venetian painter, with whom she removed to Rome.

B 210

Portrait of the Artist.

Bust, facing right. First exhibited in the P. A. F. A., I 8 I I.

Presented by Mrs. Elizabeth Powel in 1817.

\section{B 2 II}

Virtue Directed by Prudence to Avoid

the Solicitations of Folly.

\section{2}

Canvas, oval, $22 \times 25$.

Presented by Paul Beck in 1842 .

\section{Charles Robert Leslie, R.A.}

Born in London, of American parents, October 19, 1794; died in the same city, May 5, 1859. Brought by his parents to Philadelphia in 1800 . Apprenticed to a bookseller, but, showing a talent for art, was sent, through the instrumentality of the P. A. F. A., to London, in I8II. Studied in the Royal Academy with West and Allston. First exhibited there in I82I; elected an Associate the same year, and made a full Academician in 1826 . Was highly esteemed as a man, as an artist, and as an authoritative writer on art. Many of his works have been engraved in the London Art Journal. 


\section{B 212}

Print Room

George Frederick Cooke as Falstaff.

Water-Color, $5 \times 8$.

Signed on front, C. R. Leslie.

\section{B 213}

Library

George Frederick Cooke as Richard III.

Water-Color, $6 \times 8$.

Engraved by David Edwin for The Mirror of Taste, I8I I.

\section{B 214}

Library

Thomas Apthorpe Cooper as Othello.

Water-Color, $6 \times 8$.

Signed on front, C. R. Leslie.

Portrait of William Dillwyn.

Canvas, $25 \times 30$.

Bust, facing left. A Philadelphia minister in the Society of

Friends. Removed to England, where he was a friend of West and a patron of Leslie.

Bequeathed by W. S. Warder, I 832 .

\section{B 216}

The Murder of Rutland by Lord Clifford.

Shakespeare, Henry VI.

Canvas, $80 \times 96$.

Signed on front, C. R. Leslie, I8 I 5. First exhibited in P. A. F. A., I8I6. Reproduced in Academy Album.

Presented by the Leslie family, I83I.

B 2 I 7

Gypsy Belle.

Panel, $7 \times 9$.

Portrait of Charlotte Cooper, Queen of the English Gypsies. Engraved by A. Duncan for The Amulet, i830. Carey Collection.

B 218

Portrait of Henry C. Carey.

Panel, $7 \times 8$.

Bust, facing right. A distinguished American political economist. Carey Collection. 


\section{B 219}

Touchstone, Audrey, and William, in As You Like It.

Panel, I I $\times 16$.

Engraved by Alexander Lawson for The Token, 1833 . Carey Collection.

B 220

Olivia, in Twelfth Night.

Carey

Engraved

\section{Daniel Maclise, R.A.}

Born in Cork, January 25, I8II ; died in Chelsea, London, April 25, I870. Entered the Cork School of Art at the age of sixteen. Went to London in I827, and studied in the Schools of the Royal Academy. First exhibited in I829; Associate in 1835, and Academician in 1840. Decorated the Palace at Westminster, and the Royal Gallery. The latter works engraved in line for the Art Union of London.

B 22 I

Salvator Rosa painting Masaniello.

Engraved by John Sartain for The Diadem, I 846 . Carey Collection.

\section{J. Kenny Meadows.}

Born in Cardiganshire, November I, I790; died August, I874. Exhibited in the Society of British Artists, and the Royal Academy.

B 222

Jessica.

Carey Collection.

\section{Library}

Water-Color, 8 x Ir.

\section{Hoppner Meyer.}

Nephew of John Hoppner, R.A., and brother of Henry Meyer, the engraver. Visited this country and drew portraits of several prominent Philadelphians in water-color. 


\section{B $223 \quad$ Library}

Portrait of Edward L. Carey.

Water-Color Vignette.

Bust, full face. Signed on front, Hoppner Meyer, Delt., I 836 . Carey Collection.

\section{George Morland.}

Born in London, June 26, 1763; died in the same city, October 29, 1804. Studied with his father. First exhibited when a mere child in the Associated Society of Artists, $\mathbf{1 7 7 5}$, and in the Royal Academy in 1779 . Was exceedingly dissipated, spending much of his time in prison for debt. Many of his pictures were painted there. His work was very popular, and is now highly esteemed.

B 224

\section{Landscape.}

Carey Collection.
74

Canvas, $15 \times 18$.

\section{John Opie, R.A.}

Born in the village of St. Agnes, May, I76I ; died in London, April 9, I807. Buried in St. Paul's Cathedral. Received some instruction from Dr. Wolcott (Peter Pindar), but mainly self-taught. Went to London in 1780 . Elected Associate of the Royal Academy in 1787 and Academician in 1788 . Appointed Professor of Painting at the Royal Academy in 1806 , and delivered four lectures at Somerset House.

\section{B 225}

Gil Blas Securing the Cook in the Robbers' Cave. Canvas, $54 \times 84$. Presented by Paul Beck, i 842 .

\section{B 226}

Portrait of Mrs. Elizabeth Davy, of Devonshire, England.

Bust, aged woman, with cap, seated, facing front.

Presented by Miss M. S. Davy. 


\section{James Baker Pyne.}

Born in Bristol, December 5, 1800; died in Londion, July 29, 1870. Selftaught. Went to London in 1835 , and exhibited for the next four years at the Royal Academy, and at the Society of British Artists. Made a member of the latter in 1842 , and was for some years its Vice-President. Many of his works have been engraved for the London Art Journal.

\section{B 227}

\section{Sunrise on the Thames: Windsor}

Castle in the Distance.

Signed on front, J. B. Pyne, I839. Carey Collection.

B 228

\section{Sunset on the French Coast.}

Signed on front, Pyne, '36. Carey Collection.
7 I

Canvas, $24 \times 36$.

\section{William Clarkson Stanfield, R.A.}

Born in Sunderland, I794; died in Hampstead, May 18, I867. He was a sailor in early life, and, being disabled by a fall in 1818 , took up the painting of scenery. He followed this profession for several years, producing at the same time some marine pictures. First exhibited in the Royal Academy in 1827. Elected an Associate in 1832, and Academician in 1835 .

\section{B 229}

The Bay of Baiæ from Pozzuoli.
72

Canvas, $22 \times 36$.

Signed on front, C. Stanfield, R.A., i 842. Carey Collection.

\section{Henry Thomson, R.A.}

Born in London, July 31, I773; died in Portsea, April 6, I843. Pupil of John Opie, R.A. Entered the Schools of the Royal Academy in I790; elected Associate in I801, and Academician in 1804. Appointed keeper of the Royal Academy in 1825 . 
Portrait of Baron Williams.

Full length, in uniform, standing, facing left. Accompanied Captain Cook on his voyage around the world.

\section{Richard Wilson, R.A.}

Born in Pinegas, Montgomeryshire, Wales, August, I, I7 I4; died in Llanverris, Denbighshire, May I2, I782. Studied under Wright. First attained eminence as a portrait painter. Went to Italy in 1749 , and from that time painted landscape. 'One of the thirty-six original members of the Royal Academy in 1768 , and made its librarian in 1776 .

Falls of Tivoli.

Exhibited at Society of Arts, Strand, London, 1762. Reproduced in Academy Album. Carey Collection.

\section{B 232}

Landscape Study.

Carey Collection. 


\section{CONTINENTAL PICTURES BEFORE THE NINE- TEENTH CENTURY}

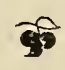

J. C. Acetdemaker.

C 300

Spaniels.

Signed on front, J. C. Acetdemaker, I650. The signature is distinct but not easily deciphered, and it is doubtful if this rendering is correct.

\section{Pieter Janszoon van Asch.}

Born in Delft, $\mathbf{1 6 0 3 . ~ T h e ~ d a t e ~ o f ~ h i s ~ d e a t h ~ i s ~ n o t ~ r e c o r d e d , ~ b u t ~ h e ~ l i v e d ~ t o ~ a ~}$ great age. Painted canvases of a small size, and was one of the most admired artists of his time.

C 301

The Fruiterers.

C 302

\section{1}

Panel, $7 \times 9$.

$7 I$

The Dutch Gardener.

Panel, $7 \times 9$.

\section{Bonifazio I.}

Commonly called Bonifazio Veronese. Born in Verona; died, 1540. A pupil of Palma Vecchio. His works are to be seen in most Italian Galleries, also at Dresden, Vienna, St. Petersburg, and Paris. 


\section{The Last Supper. \\ C 303 \\ Print Room \\ Canvas, $18 \times 35$.}

Presented by Mr. and Mrs. John W. Field, I 887.

\section{Nicolas Bosschaert.}

Born in Antwerp, 1696. Studied with Crepu. Became eminent as a painter of fruit and flowers, and was frequently employed to paint the same in the pictures of contemporary artists.

\section{304}

Flower Piece.

68

Canvas, $24 \times 28$.

The vase by Lyssens. Signed on front, Bosschaert.

Legacy of Talbot Hamilton, I 820.

Flower Piece.

C 305
68

The vase by Lyssens. Signed on front, Bosschaert.

Legacy of Talbot Hamilton, I 820.

\section{Campidoglio (Michael Angelo Pace).}

Born in Rome, I6ro; died in I670. Called Di Campidoglio from an office he held in the Campidoglio or Capitol at Rome. Studied with Fioravanti.

\section{306}

Fruit.
67

Canvas, $51 \times 62$.

\section{Jacques Louis David.}

Born in Paris, August 30, 1748; died in Brussels, December 29, I 825. Studied under Vien. Obtained the Prix de Rome in 1774 . Returned to France in I 780 . Was admitted to the Academy in 1783 ; one of the original members of the Institute, I795. Napoleon made him Court Painter and gave him many important commissions. On the restoration of the Bourbons he sought refuge at Brussels, where he remained until his death. See portrait, A 70. 


\section{307}

67

Samson and Delilah.

First exhibited in P. A. F. A., 1821 .

\section{Paulus De Vries.}

Born in Antwerp, 1554; died in 1598 . He was specially employed in the service of the Emperor at Prague.

C 308

Landscape.

Signed on back, P. Vries.
$6 \mathrm{~g}$

Panel, $16 \times 18$.

\section{Joseph Sifrède Duplessis.}

Born at Carpentras, near Avignon, 1725 ; died at Versailles, 1802 . Taught by his father, Duplessis the elder, and afterwards by Frère Imbert. Visited Rome, 1745, and studied with Subleyras. Received into French Academy, I774. Lost his fortune in the Revolution and accepted post of Conservator of the Museum of Versailles. He possessed a high reputation for his portraits, among which are those of Glück, Franklin, Marmontel, the Abbé Bossuet, and M. and Mme. Necker.

Portrait of Benjamin Franklin.

Bust, facing front. Painted from life in Paris, 1778 .

Deposited by Dr. Clifford F. Snyder, Berlin, Germany, I 894 .

\section{Benozzo Gozzoli.}

Born in Florence, 1420; died 1498. Studied with Fra Angelico. Acted as his assistant at Orvieto, I447. Decorated many churches and chapels. His most important work was the fresco in the Campo Santo at Pisa, consisting of twentyfour designs, requiring, with the aid of his assistants, sixteen years to complete. 
Virgin and Child.

C 310

Library

Canvas, $22 \times 28$.

Reproduced in Academy Album.

Presented by Mr. and Mrs. John W. Field, I 887.

\section{Guido Reni.}

Born in Calvenzano, near Bologna, 1575; died in Bologna, 1642. Studied with the Caracci and Ferrantini. He went to Rome in 1596, and spent some time in Naples, where he painted the Nativity, considered his best work. $\mathrm{He}$ was an industrious artist. The churches and palazzi are full of his pictures, and scarcely a gallery in Europe is without an example of his work.

\section{3II}

68

Ganymede, Jove's Cup-Bearer.

Canvas, $14 \times 18$.

Bust, profile, facing left.

Presented by Joseph Allen Smith, of South Carolina, r8 I 2.

\section{J. van Hiet.}

\section{312}

68

Portrait of a Woman in a Hood.

Panel, $23 \times 28$.

Bust, facing front. Signed on front with a monogram: V.

Hiet, r651. On back, J. Van-Hiet, Pinx ÆT. SVÆ— $66 \mathrm{~A}^{\circ} \mathrm{r} 65 \mathrm{r}$.

\section{Charles Le Brun.}

Born in Paris, February 24, 1619; died in the same city, February 12, 1690. Studied with his father, a sculptor, and with a painter named Perrier. Accompanied Poussin to Italy in I642. On his return became, through the patronage of Louis XIV., the head of the French school. In I648 he took the principal part in the foundation of the Academy, and was the first director of the Gobelins manufactory, painting meanwhile for his royal patron and designing fountains, statues, and decorations for Versailles. 


\section{313}

Time and Truth correcting Love.

First exhibited in P. A. F. A. in 18 I 9 .

\section{Pieter van Lint.}

Born in Antwerp in 1609; died in the same place, 1690. Studied under Roeland Jacobs. Went to Italy in $\mathbf{I} 633$, and spent some years at Rome, where he decorated several cathedrals.

\section{314}

St. Mark Writing his Gospel.

Presented by Paul Beck, i 842 .

\section{Andrea Lucatelli.}

Born in Rome, 1660; died, I741. Studied under Paolo Anesi.

$$
\text { C } 315
$$

Landscape, Ray Fishing, etc.

Canvas, I4 $\mathrm{x}$ I9.

\section{Pieter Molyn.}

Born in London about $\mathbf{1 6 0 0}$; died in Haarlem, $166 \mathbf{I}$. Went to Haarlem in I6I6, where he became a member of the Guild and its President in 1633 . His works are rare and highly esteemed.

$$
\text { C } 316
$$

Portrait of Nicolas Duval.

Panel, 21 x 26.

Bust, facing right. Signed on front with monogram, P. M.1635. The following inscription is on the back: Sr. DV Val. Le Pere. De Sr. R Dv Val . Peintre. De Sa Majeste Guill III Le Roy De Grand Britannie. 


\section{Pieter Neeffs.}

Born in Antwerp, 1577 or 1578 ; died between 1657 and I66I. Pupil of Hendrik van Steenwyk the elder. Celebrated for his cathedral interiors. Many of his best pictures are in England; but Paris, Amsterdam, Munich, Vienna, and St. Petersburg are also rich in his works.

\section{C $3 \mathrm{I} 7$}

Interior of a Cathedral, with Figures by Teniers. Canvas, II $\times 17$

\section{Michel Barthélemy Ollivier.}

Born in Marseilles, 1712 ; died in Paris, June $15, \mathrm{r} 784$. Lived a number of years in Spain, where there are many of his works. Member of the Academy of St. Luke, and appointed painter to the Prince de Conti.

$\mathrm{C}_{318}$

Fête Champêtre.

C 319
67

Canvas, $13 \times$ I 7 .

67

Fête Champêtre.

Canvas, $13 \times 17$.

\section{Adriaan Janszoon van Ostade.}

Born in Haarlem, December 10, I610; died in Amsterdam, April 27, I685. Studied with Frans Hals. Began as a painter in Haarlem, where his name is first recorded as a member of the civic guard in 1636 . On the approach of the French troops, in I662, he went to Amsterdam, where he continued his profession until his death.

C 320

Interior, with Figures and Still-Life.

C 32 I

Interior.

Signed on front, A. O.
69

Panel, $12 \times 16$.

Panel, I5 x 18. 


\section{Giovanni Paolo Pannini.}

Born in Piacenza, I69I or 1695 ; died in 1764 . Went early to Rome, where he studied with Andrea Lucatelli and Benedetto Luti, but adopted the style of Salvator Rosa. Was a member of the Academies of San Luca, Rome, and Paris.

\section{322}

Banditti among Antique Ruins.

Presented by Mrs. John Ford.

\section{323}

96

Banditti among Antique Ruins.

Presented by Mrs. John Ford.

\section{Cornelis van Poelenburg.}

Born in Utrecht, I586; died in the same place, August I2, I667. Studied with Abraham Bloemaert and in Italy. In 1607 Charles I. invited him to London, where he painted several pictures for the king and nobility. Returned to Utrecht, where, in 1649, he was made President of the Painters' Guild. Examples of his work are in nearly all the galleries of Europe.
Nymphs.

\section{324}

\section{Francesco di Marco Raibolini.}

Born in Bologna, I450; died in the same place, January 5, 1517. Acquired great reputation for his designs in silver and gold, and was appointed by the Prince of Bologna Master of the Mint, an office which he held until his death. Is supposed to have studied painting with Costa and to have been influenced by Raphael. Vasari says of him that he was reverenced as a god in Bologna.

\section{325}

\section{Print Room}

Virgin.

Presented by Mr. and Mrs. John W. Field, I 887. 


\section{Salvator Rosa.}

Born at Arenella, near Naples, 1615; died in Rome, 1673. Studied with Francesco Francanzani. Lived for a while among the banditti of the Abruzzi. Went to Rome in $\mathbf{1} 634$, and in 1647 joined the revolution in Naples under Masaniello. After the latter's death, returned to Rome, where he was threatened by the Inquisition, and fled to Florence, but returned to Rome in 1652 , and remained there until his death.

An Old Man's Head.

Profile, facing right.

An Old Man's Head.

Looking down, facing left.

Landscape.

Presented by Joseph Allen Smith, of South Carolina, I8I 2.

\section{329}

Landscape.

Canvas, $20 \times 26$.

Presented by Joseph Allen Smith, of South Carolina, I8 I 2.

\section{330}

108

Landscape. Mercury Deceiving Argus.

Canvas, $48 \times 73$.

Presented by Joseph Allen Smith, of South Carolina, I 8 I 2.

\section{Bartolommeo Schidone.}

Born in Modena, 1560; died in Parma, 1616. Studied with the Caracci, though his work bears more resemblance to the style of Raphael and Correggio than that of his masters. His pictures are extremely rare.

$$
\begin{array}{ll}
\text { C } 331 & 67
\end{array}
$$

Cupid with a Vase.

Presented by Joseph Allen Smith, of South Carolina, I 8 I 2. 
Cupid Musing.

\section{Frans Snyders.}

Born in Antwerp, 1579; died in same place, 1657. Instructed by Hendrik van Balen and P. Breughel. His talent excited the admiration of Rubens, who frequently intrusted him to paint the animals, fruits, etc., in his pictures. Was employed by the Archduke Albert of Brussels, and by the King of Spain. Vandyck painted his portrait more than once.
Dead Game and Dòg.

Dog and Heron.

\section{334}

C 335

Boar-Hunt.

C 336
95

Canvas, $27 \times 35$.

53

14

Canvas, $51 \times 76$.

Dead Game and Fruit.

Presented by Mrs. Bloomfield Moore, r $88 \mathrm{r}$.

\section{Storks.}

Seaport in Holland'.

\section{Dominicus van Tol.}

Born in Bodegraven, between $\mathbf{I} 63 \mathbf{I}$ and $\mathbf{I} 642$; died in Leyden, $\mathbf{1 6 7 6 .}$ He was the nephew and pupil of Gerard Dou. Lived for a time at Amsterdam, but the greater part of his life was passed at Leyden.

The Cherry-Girl.

C $33^{8}$

Signed on front, D. v. T.
67

Panel, I4 x 17. 


\section{Unknown.}

C 339

St. Jerome.

An example of the Spanish school.
C 340

Landscape. Sunset.
96

Canvas, $29 \times 36$.

7 I

Netal, 9 x r2.

68

Panel, I4 x I9.

A Belgian Head.

C 342

Young man with cap. Profile, facing right.

\section{343}

69

Martyrdom of St. Catherine.

Canvas, $14 \times 19$.

Presented by Col. Cephas G. Childs, I 847.

\section{344}

I3

Judith with the Head of Holofernes.

Ascribed to Domenichino.

Deposited by Mrs. G. H. Schneider, I 885 .

\section{345}

107

Cecil Calvert, Second Lord Baltimore, Proprie-

tary of the Province and Founder of the

State of Maryland.

Canvas, $58 \times 95$.

Full length, standing; dressed in coat and small-clothes of blue velvet. The right hand raised, with baton pointing to two ships in the distance, probably representing the Ark and the Dove, in which the first colony sailed for America. The arrows in the foreground denote the yearly tribute of "two Indian arrows to be delivered at Windsor Castle every year," etc. Ascribed to Vandyck. Gift of Queen Anne to the City of Annapolis.

Deposited by Titian Ramsey Peale, I 877. 
Van der Drasbach.

C 346

69

A Dutch Courtship.

\section{Bartholomeus van der Helst.}

Born in Haarlem, 1613; died in Amsterdam, December 16, 1670. Supposed to have studied with Nicolas Elias and Frans Hals. Was one of the foundation members of the Painters' Guild, I654. Occasionally painted civic scenes and shooting pieces, but his better known and more numerous works are portraits and portrait groups.

The Violinist.

\section{347}

One of the finest examples of figure-painting of the Dutch school. Reproduced in Academy Album.

\section{Antoine François van der Meulen.}

Born in Brussels, 1634; died in Paris, October I5, I69o. Studied under Peter Snayers. Was invited to Paris, pensioned by Louis XIV., and given apartments at the Gobelins, where he was employed on designs for tapestry. In I673 he was received as a member of the Academy. The king heaped riches and distinctions upon him.
A Cavalry Charge.
C 348
69
Panel, $15 \times 23$.
A Battle Scene.

\section{Egbert van der Poel.}

Probably born in Delft, where he was baptized, March 9, I62I ; died in Rotterdam, I664. Became a member of the Guild at Delft about 1650 . Removed to Rotterdam in 1654 . 


\section{350}

Portrait of a Cavalier.
75

Panel, $7 \times$ ro.

Bust, facing right.

Presented by J. B. Freeman.

\section{Jan van Goyen.}

Born in Leyden, I596; died in The Hague, 1666. Studied with Esaias van de Velde. Went to The Hague in $163 \mathrm{I}$, where he was elected a member of the Painters' Guild in 1640. He was one of the earliest of the Dutch landscape painters.

\section{35 I}

A River Scene.
96

Panel, $24 \times 33$.

Presented by Mrs. John Ford.

\section{Claude Joseph Vernet.}

Born in Avignon, August 14, 1714; died in the Louvre, Paris, December 3, I789. Received instruction from his father. Went to Rome and entered the school of the marine painter Bernardo Fergioni; also studied under Adrien Manglard, Pannini, Lucatelli, and Solimena. On his return to France he was admitted, in $\mathbf{r} 753$, to the Academy, and in $\mathbf{1 7 7 6}$, to its council. Louis XV. commissioned him to paint a set of twenty pictures of French seaports, but, owing to war with England, only sixteen were finished: these are now in the Louvre.

\section{352}

The Royal Family of Naples at Portici.

Canvas, $52 \times$ I2r.

Portraits, with castle and village in the distance. Signed on front, Joseph Vernet, Fect., I 746. Purchased at the Joseph Bonaparte sale, Bordentown, N.J., September I7, I8, I845.

\section{353}

Shipwreck.

Canvas, $60 \times \mathbf{x} 23$.

Signed on front, Joseph Vernet, I782. Purchased at the Joseph Bonaparte sale, Bordentown, N.J., September I7, I8, I 845 . 


\section{C $354 \quad 26$}

Marine.

Canvas, $27 \times 39$.

Purchased at the Joseph Bonaparte sale, Bordentown, N.J., September I 7, I 8, I 845 .

C 355

26

Marine.

Canvas, $28 \times 40$.

Purchased at the Joseph Bonaparte sale, Bordentown, N.J., September I 7, I8, I 845 .

\section{Paolo Veronese (Paolo Caliari).}

Born in Verona, 1528; died in Venice, April 19, 1588. Son of a sculptor. Educated first in that branch of art, but soon abandoned it for painting. Went to Venice in $\mathbf{1 5 5 5}$, where he decorated many churches and palaces. Noted for his rich color. His work is treasured in the principal galleries of the world.

St. John the Baptist.

\section{356}

Presented by Mr. and Mrs. John W. Field, I 887.

\section{Print Room}

Canvas, $16 \times 20$.

\section{Andrea Vicentino (Andrea dei Michieli).}

Born in Venice, I539; died, I6I4. Was a pupil of the elder Palma. Employed to paint several works representing the history of the Republic in the Sala del Gran Consiglio of the Palace of St. Mark.

\section{357}

Adoration of the Magi.
103

Canvas, $57 \times 72$.

Presented by Paul Beck, i 842 .

\section{Hendrik Cornelis .Vroom.}

Born in Haarlem, 1566; died in the same place, 1640. Son of a sculptor. Visited Spain and Italy, and for two years was employed by Cardinal dei 
Medici. He made the designs of the famous tapestries executed for Lord Nottingham by Frans Spiering, representing the defeat of the Spanish Armada, which were destroyed by fire in the House of Parliament, 1834 .

\section{C $35^{8}$}

Embarkation.
70

Canvas, $22 \times 39$.

\section{Philip Wouwerman.}

Born in Haarlem, 1614; died in the same place, 1668. Studied under his father and Jan Wijnants. Went to Hamburg at the age of nineteen, working in the studio of Everard Decker. Returned to Haarlem, 1640, and was received into the Guild of St. Luke. He did a prodigious amount of work in his brief career, and his pictures are highly prized in the principal galleries of the world.

\section{359}

Cavalry Halt.
69

Canvas, I $_{5} \mathrm{x}+8$.

Presented by William H. Stewart, I 860. 


\section{CONTINENTAL PICTURES OF THE NINETEENTH CENTURY}

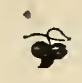

\section{François Bossuet.}

Born —- ; died in Antwerp, September 28, I889. Officer of the Order of Leopold.

\section{400}

\section{Roman Aqueduct and Moorish}

Ruins at Alcalá, Spain.

Signed on front, F. Bossuet, Bruxelles, I 850.

\section{William Adolph Bouguereau.}

Born in La Rochelle, France, November 20, I825. Pupil of Picot and l'École des Beaux-Arts, Paris. Gained the Second Grand Prize, and went to Rome, 1848. Exhibited his picture, The Body of St. Cecilia borne to the Catacombs, now in the Luxembourg, in 1855 . Medal, I857; Medals, Universal Exposition, 1855 and 1867 ; Medal of Honor, Universal Exposition, I878; Knight of Order of Leopold, I88I ; Grand Medal of Honor, 1885 ; Medal of Honor, Antwerp, I885. Member of the Institute of France and Officer of the Legion of Honor.

\section{401}

Orestes pursued by the Furies.

Canvas, 9 I $\mathrm{x}$ IIo.

Signed on front, W. Bouguereau, I862. Reproduced in Academy Album.

Presented by Mrs. Joseph Harrison, I 878. 


\section{A. Correlli.}

\section{402}

A Golden Opportunity.

Signed on front, A. Correlli, Rome, I88I.

Presented by Joseph E. Temple, I $88_{4}$.

\section{Thomas Couture.}

Born in Senlis, December 2I, I8I5; died in Villiers-le-Bel, March 27, I879. Studied under Gros and Paul Delaroche. Second Grand Prix de Rome, I837. Received Medals in $1844, \mathbf{I} 847$, and 1855 , and the Legion of Honor, I848. His fame rests chiefly on the picture bought by the French Government, now in the Luxembourg, The Romans in the Decadence of the Empire.

A Court-Yard.

D 403

Print Room

Crayon, Io $\mathrm{xI}_{3}$.

Signed on front, T. C.

Presented by Mr. and Mirs. John W. Field, I 887.

\section{F. Brenhaus De Groot.}

D 404

Landscape.

Canvas, $40 \times 56$.

Signed on front, F. Bren-de Groot.

\section{Charles Auguste Emile Carolus-Duran.}

Born in Lille, France, July 4, I837. Went to Paris, I853, and to Italy, I86I. Lived with the monks of Subiaco. Medal, Salon, I865, and also I869 and I870. Chevalier of the Legion of Honor and of the Order of Leopold, I 879.

\section{405}

Portrait of Helena Modjeska Chlapowski.

Canvas, 4 I $\times 75$.

Full length, standing, face front. Distinguished tragédienne, Signed on front, at top, Carolus-Duran, Paris, i 878. Reproduced in Academy Album.

Presented by Paris Haldeman, I 883 . 


\section{Jacob Joseph Eeckhout.}

Born in Antwerp, 1793; died in Paris, 1861. Studied in the Academy of Antwerp. Elected a member of the Academies of Antwerp, Amsterdam, Brussels, and Rotterdam in I829. Went to The Hague in $\mathbf{I} 83 \mathbf{I}$, and in 1839 became a Director of the Academy in that city. Went to Paris in 1859.

\section{406}

67

Gentleman and his Valet.

Panel, ro $x$ I4.

\section{Friedrich August Elsasser.}

Born in Berlin, 1810 ; died in Rome, $\mathbf{1 8 4 5 .}$ Studied in the Berlin Academy under Blechen. Went to Italy in $183 \mathbf{I}$, and visited Sicily in $\mathbf{I} 834$ and $\mathbf{r} 835$. The King of Prussia decorated him with the Order of the Red Eagle, and granted him a pension for life.

D 407

View in Calabria.

Signed on front, F. A. Elsasser, Roma. Carey Collection.

\section{Federigo Faruffini.}

Born in Sesto San Giovanni, near Milan, Italy, August I2, r833; died in Perugia, December 20, 1870. Studied in Rome. Distinguished both as a painter and as an engraver.

\section{408}

\section{Cæsar Borgia and Macchiavelli.}

Canvas, $79 \times 140$.

Signed on front, Faruffini. Considered the finest work of the artist. Engraved by him. Gold Medal, Paris, I 866. Reproduced in Academy Album.

Presented by Thirty-Six Subscribers, I 870.

\section{Mariano Fortuny.}

Born in Reus, near Barcelona, I838; died in Rome, November 24, I874. Studied at the Academy of Barcelona. Received the Prix de Rome, I858. 
Accompanied General Prim, as a member of his staff, to Morocco. Returned to Rome after the war, where his life was chiefly spent.

\section{409}

The Model. A Sketch.

Signed on front, Fortuny.

Presented by Edward H. Coates, I880.

\section{André Gastaldi.}

Professor of Painting, Académie Albertine des Beaux-Arts, Turin. Medal,

Paris Exposition, 1855. Honorary Member of the P. A. F. A., I867.

\section{410}

The Duke of Este meditating the Death

of his Wife, Parisina.

Canvas, $80 \times 95$.

Signed on front, A. Gastaldi. A scene from Byron's poem Parisina. Medal, Paris Exposition, 1855. Reproduced in Academy Album.

Purchased by P. A. F. A., I 867.

\section{F. Gonne.}

Professor of Painting at Dresden.

\section{$D_{4 I I}$}

Clown in a State of Dejection.

Canvas, $40 \times 56$.

Signed on front, F. Gonne, Pinx., I 854 .

Presented by a lady in Dresden, through Consul Charles Vezin, i86I.

\section{Alfred Gues.}

Born in Montargis. Pupil of Gleyre. First exhibited, Salon, I863. 


\section{412}

The Standard-Bearer.

Signed on front, A. Gues.

Presented by John Pondir, 1877.

\section{Godefroid Guffens.}

Born in Hasselt, Belgium, I803. Pupil of Nicaise de Keyser. Began his career in Brussels, 1824. Settled in Antwerp, where there are numerous mural paintings by him in the Church of St. George. Chevalier of the Order of the Red Eagle of Prussia; of the Order of Leopold of Belgium; and of the White Falcon.

\section{4 I3}

Rouget de Lisle, a French Officer, singing for the first time the Marseillaise, of which he was the author, at the house of the Mayor of Strasbourg, 1792 .

Signed on front, Godefroid Guffens, I 849.

\section{Charles Hermans.}

Belgian Gold Medal, Brussels Salon, 1869. Chevalier of the Order of Leopold, I 875 ; Chevalier of the Order of Francis Joseph of Austria.

\section{D $4 \mathrm{I} 4$}

Maşked Ball at the Opera House.

Signed on front, Hermans.

Presented by Joseph E. Temple, I 882 .

\section{Karl Wilhelm Hübner.}

Born in Königsberg, I 814; died in Dïsseldorf, I 879. Studied at Düsseldort Academy under IV. von Schadow and K. Sohn. Visited America in 1874-5. Chevalier of the Order of Leopold. Royal Professor at Düsseldorf. Member of the Academy of Amsterdam. Medal at Metz. 
D $4 \mathrm{I} 5$

The Recovery.
54

Canvas, $42 \times 53$.

Signed on front, Carl Hübner, Düsseldorf, I 850.

\section{Paul Emil Jacobs.}

Born in Gotha, 1803 ; died in the same place, I866. Studied with Peter Langer, at the Munich Academy, I8IS-25; afterwards for three years in Rome. Went to St. Petersburg in 1830 , and was there made a member of the Academy. Travelled in Greece, I 838 . Returned to Gotha, I840, and was appointed Court Painter.

$D_{4} \mathrm{I} 6$

Judith and Holofernes.

\section{3}

Canvas, $48 \times 59$.

\section{Peter Johann Theodor Janssen.}

Born in Düsseldorf, Germany, I844. Studied at the Düsseldorf Academy, under E. Bendemann. Visited Munich, Dresden, and Holland. Professor of the Diisseldorf Academy in 1877, and Director in 1880 . Member of Berlin Academy, 1885 . Has decorated many important buildings and churches in his native country.

\section{Peter Denying Christ.}

Signed on front, F. Janssen, I869. Reproduced in Academy Album.

Presented in 1876 by a Number of Subscribers.

\section{Wilhelm von Kaulbach.}

Born in Arolsen, Westphalia, ISo5; died in Munich, 1874. Entered the Düsseldorf Academy, under Cornelius, at the age of seventeen, and accompanied him in I 825 to Munich. Director of the Munich Academy, Officer of the Legion of Honor, 1867, Member of several Academies, and received many decorations. Commander of Order of Francis Joseph; Grand Commander of Order of St. Michael. 


\section{D $418 \quad 56$}

Ludwig I., King of Bavaria.

Canvas, $48 \times 65$.

Signed on front, W. Kaulbach. Full length, standing in front of throne, with four pages kneeling in attendance.

Bequeathed by Chas. F. Hagedorn, 1869.

\section{E. Koster.}

D 419

View of Dresden.

Canvas, $45 \times 69$.

Signed on front, E. Koster, ft.-Dresden.

Bequeathed by Mrs. Tobias Wagner, 1885 .

\section{Emanuel Leutze, N.A.}

Born in Nuremberg, Bavaria, May 24, I816; died in Washington, D.C., July 18, I868. Brought to Philadelphia when a child. Went to Diisseldorf and Italy to study in 1841 . Returned to America in 1859 . Academician, N. A. D., I 860 .

D 420

The Poet's Dream.

Carey Collection.
I9

Canvas, $25 \times 30$.

\section{Edmund de Pratere.}

Gold Medal, Brussels Salon, I878; Chevalier of the Order of Leopold, I881 ; Gold Medal, Melbourne, I88I; Medals at London and Philadelphia.

\section{D $42 I$}

Two Members of the Temperance Society.

Signed on front, Edn. de Pratere, 1882.

Presented by Joseph E. Temple, I 882 . 
Pierre Etienne Théodore Rousseau.

Born in Paris, April 15, I812; died in Barbizon, December 22, I867. Studied under Pau de St.-Martin, Rémond, and Guillon-Lethière. First exhibited in the Salon of 1834. Received Medal of First Class, I849; Cross of the Legion of Honor, 1852 ; Medal of Honor and made an Officer of the Legion of Honor, I 867 .

\section{422}

\section{Landscape.}

\section{Print Room}

Canvas, $9 \times 13$.

Signed on front, Th. Rousseau,-5 I .

Presented by Mr. and Mrs. John W. Field, I 887.

\section{Christian Schuessele, P.A.}

Born in Gebweiler, Alsace, April 16, 1824; died in Merchantville, N.J., August 20, 1879. Studied under Guérin, Paul Delaroche, and Yvon. Came to this country about 1848 , and settled in Philadelphia. Professor of Drawing and Painting, P. A. F. A., from I 868 to 1879 .

\section{423 Print Room}

Child Sleeping.

Signed on front, C. Schuessele.

Presented by Dr. Francis W. Lewis, I 880.

\section{George Schwartze.}

Pupil of Leutze. Studied at Amsterdam.

$$
\text { D } 424
$$

The Three Marys.

First shown in Exhibition Artists' Fund Rooms, 1837.

Presented by the Artist. 


\section{H. Schweninger.}

\section{425}

\section{David returning Thanks for his Victory}

over Goliath.

Signed on front, H. Schweninger, Wien.

\section{Alexandre Struys.}

Professor in the Academy at Weimar. Chevalier of the Order of the White Falcon of Saxony, 1878.

D 426

Forgotten.
64

Signed on front, Alexandre Struys, Weimar, 1879.

Presented by Joseph E. Temple, I 882.

\section{Alexandre Thomas.}

Brussels. Gold Medals, Paris and Brussels. Officer of the Order of Leopold; Chevalier of the Order of the Iron Crown of Austria.

\section{427}

Christ after the Descent from the Cross.

Signed on front, A. Thomas.

Presented by Joseph E. Temple, I882.

\section{Paul Désiré Trouillebert.}

Born in Paris. Pupil of Hébert and Jalabert. Has painted a number of portraits of distinguished persons, and some compositions and landscapes.

$$
\text { D } 428
$$

Landscape.

Signed on front, Trouillebert.

Presented by Francis W. Lewis, M.D., I 894.

76
I06

Canvas, $88 \times 107$. 


\section{Camille Troyon.}

\section{429}

\section{Fontainebleau.}

\section{Print Room}

Water-Color, $7 \mathrm{x}$ Io.

Signed on front, C. T.

Presented by Mr. and Mrs. John W. Field, I 887.

\section{Paul Weber, A.P.A.}

Born in Germany about 1823. Studied at Frankfort. Came to the United States, I848, and settled in Philadelphia. Trarelled in Scotland and Germany, 1857. Went to Darmstadt, I858, and was there appointed Court Painter.

\section{430}

Landscape. Evening.

Signed on front, Paul Weber, i $8 ; 6$.

\section{Adolph Weisz.}

D 431

Forbidden Roses.
63

Canvas, $4 \mathrm{I} \times 60$.

Signed on front, A. Weisz, Paris, I882.

Presented by Mrs. Bloomfield Moore, 1883.

\section{Johann Bernard Wittkamp.}

Born in Riesenbeck, Westphalia, September 9, I820; died in Antwerp, January 15, I885. Studied at Rotterdam, with Wilhelm Hendrik Schmidt, and at the Royal Academy of Painting, Antwerp. Medals at The Hague, Bruges, London, and Centennial Exhibition at Philadelphia. Honorary Member P. A. F. A. 


\section{D $432 \quad 56$}

The Deliverance of Leyden from the Siege by the Spaniards under Valdez, in I574. Canvas, $167 \times 263$.

Signed on front, J. B. Wittkamp, I848. Reproduced in Academy Album.

Purchased by P. A. F. A., I85 I.

D 433

Datheen Preaching before the Walls of Ghent during the Struggle for Independence of the Netherlands, when under the Dominion of Spain, in the Sixteenth Century.

Signed on front, J. B. Wittkamp. I 852 .

\section{434}

First Ray of Sunlight after an Arctic Winter. Canvas, $65 \times 89$.

Signed on front, J. B. Wittkamp.

Presented by Mrs. Joseph Harrison, I 878. 


\section{A MERICAN SCULPTURE \\ के \\ Hugh Cannon.}

The place and date of his birth and of his death are unknown. Was probably of Irish extraction and born in the early part of this century. Originally a marble-cutter. Self-taught.

\section{A 500}

Bust of Nicholas Biddle.

Marble.

\section{A 501}

Bust of Henry Clay.

Marble.

Presented by D. W. Coxe, i 850.

\section{A 502}

Bust of Hugh Cannon.

Marble.

Presented by D. W. Coxe, 1850 .

\section{Shobal Vail Clevenger.}

Born in Middletown, O., October 22, I $\delta \mathbf{1} 2$; died at sea, near Gibraltar, September 23, I843. Self-taught. Went to Rome, I840, where he contracted consumption. Executed busts of many prominent Americans.

\section{A 503}

Bust of Washington Allston.

Plaster.

\section{A 504}

Bust of Isaac P. Davis.

Plaster. 
A 505

Bust of Joseph Hopkinson.

Plaster.

\section{Thomas Crawford.}

Born in New York City, March 22, I8I4; died in London, September I0, I 857. Went to Italy, I 834. Studied with Thorwaldsen. Executed many important works, including Orpheus, Boston Museum of Fine Arts; Washington, Richmond, Va.; and the statue of Liberty surmounting the dome of the Capitol at Washington.

\section{A 506}

\section{Steam and Electricity.}

Plaster.

From the original model of the decorations over the entrance of the General Post-Office at Washington. Placed above stairway within eastern entrance to main corridor.

\section{Henry Jackson Ellicott.}

Born in Anne Arundel County, Md., June 23, $18_{47}$. Studied drawing at Academy of Design, New York, and under Bromedi, Powell, and Leutze. Has been engaged chiefly in modelling military monuments.

John Sartain.

\section{A 507}

Bas-relief. Profile. Signed on front, H. J. Ellicott, Sc. Presented by the Sculptor, I 892.

\section{John Frazee, N.A.}

Born in Rahway, N.J., July I8, I790; died in Crompton Mills, R. I , February 24, I852. Self-taught. Distinguished as the first sculptor of American birth and parentage.

\section{A 508}

Bust of Chief Justice Marshall.

Plaster. 


\section{A 509}

Bust of John Frazee.

Plaster.

Signed, J. Frazee, se ipsum . fecit Anno. L.A.LII.

\section{Daniel Chester French.}

Born in Exeter, New Hampshire, 1850. Pupil of Thomas Ball. Member Society American Artists. International Board of Judges, World's Columbian Exposition, I893.

\section{A 510}

The Angel of Death and the Sculptor. Plaster.

Copy of the Milmore Memorial in Forest Hills Cemetery, Boston, Mass.

\section{Charles Grafly.}

Born in Philadelphia, December 3,1863 . Studied at the Spring Garden Institute, Philadelphia; P. A. F. A.; and in Paris. Pupil of Chapu. Received First Medal for Sculpture at the Julian Academy, Paris; Honorable Mention at Salon, Paris, I89r, and P. A. F. A., Temple Fund, I891; Medal, World's Columbian Exposition, 1893.

\section{A 5 II}

Bust of Dædalus.

Bronze.

Signed, Grafly, Paris, I $88 \mathrm{~g}$. Original model purchased and cast in bronze by P. A. F. A., at Philadelphia, I89 I.

\section{Horatio Greenough.}

Born in Boston, September 6, 1805 ; died in Somerville, Mass, December I8, 1852. Went to Europe in 1824 , studying in Paris and Rome. Finally settled in Florence, where he lived for many years. Returned to America in I $S_{5}$ I.

\section{A 5 I2}

Bust of Lafayette.

Marble

Signed with monogram, H. G. 


\section{Joseph Mozier.}

Born in Burlington, Vt., August 22, I812 ; died in Faido, Switzerland, October, I870. Removed to New York, I831, where, after fourteen years spent in mercantile pursuits, he retired from business, and shortly afterward went to Europe, studying sculpture in Rome and Florence.

The Prodigal Son.

\section{A 5 I3}

Group, signed, Mozier, Sc., Rome.

Marble.

Presented by J. Gillingham Fell, I 869.

\section{Erastus Dow Palmer.}

Born in Onondaga County, N.Y., April 2, I $8 \mathbf{I} 7$. Carpenter by trade. Settled in Albany, $\mathbf{1} 846$. Began his professional career as a cutter of cameos, pursuing this branch of art until 1852 , when he abandoned it for sculpture.

Bust of Spring.

\section{A 514}

Marble.

\section{Hiram Powers.}

Born in Woodstock, Vt., July 29, I805; died in Florence, June 27, I873. Taken when a boy to Cincinnati, O., where he learned the art of modelling. After a short residence in Washington, D.C., went to Italy and settled in Florence, I 837 . The rest of his life was spent there. His fame rests chiefly upon his Greek Slave, I843, of which he made six or eight copies.

Bust of Proserpine.

\section{A 515}

Signed, H. Powers. Marble.

Presented by John Livezey.

\section{Howard Roberts.}

Born in Philadelphia. Studied in P. A. F. A., and at the École des BeauxArts, Paris. 


\section{A 516}

Hypatia.

Marble.

Signed, H. Roberts.

Loaned by the Artist.

\section{A $5 \mathrm{I} 7$}

La Première Pose.

Marble.

Signed, H. Roberts, I 876.

Loaned by the Artist.

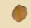

\section{Randolph Rogers.}

Born in Waterloo, N.Y., July 6, I825; died in Florence, Italy, January 20, I892. Went to Rome at an early age. Designed the doors of the Capitol at Washington, I858. Finished the Washington Monument at Richmond, left uncompleted by Crawford. Statue of Lincoln at Philadelphia, completed I87 I, and of Seward, New York, 1876.

Bust of Abraham Lincoln.

\section{A 518}

Presented by Richard D. Wood, i 866.

Marble.

\section{William Rush, P.A.}

Born in Philadelphia, July 4, 1756; died in same city, January $17, \mathbf{1} 833$. Apprenticed to a wood-carver in his youth. Became known as a carver of figure-heads for ships, and, later, of busts of eminent persons. Worked only in wood and clay. Served in the Revolutionary army. Was a member of the Council of Philadelphia for more than a quarter of a century. One of the founders P. A. F. A., and Director until his death.

\section{A 519}

Bust of William Rush.

Cast from the original carved from a pine knot. 


\section{Edmund Austin Stewardson.}

Born in Philadelphia, I860; died 1892. Studied in P. A. F. A., and at the École des Beaux-Arts; also under Allar and Chapu.

\section{A 520}

The Bather.

Plaster.

Signed, Stewardson, I 890.

Presented by Thomas Stewardson, I 893.

\section{A $52 \mathrm{t}$}

Portrait of a Lady.

Bronze.

Signed, Edmund A. Stewardson, Sculptor.

Presented by Thomas Stewardson, 1893.

\section{A 522}

Bust of Alexander Harrison.

Bronze.

Signed, E. A. Stewardson.

Presented by Thomas Stewardson, I 894.

\section{William Wetmore Story.}

Born in Salem, Mass., February I2, I819. Studied law, and has published some treatises considered valuable in that profession. Has also issued several volumes of poems, and a life of his father, Justice Story. Adopted sculpture as a profession and went to Rome, where he has spent the greater part of his life.

\section{A 523}

Jerusalem.

Marbie.

Female figure, seated. Heroic size. Signed with monogram, W. W. S., Rome, I873.

Presented by Mrs. Nancy Grigg, I 873 . 


\section{B R I T I S H SCULPTURE}

\%

\section{John Graham Lough.}

Born in Greenhead, Northumberland, 1806; died April 8, 1876. First exhibited in the Royal Academy, I826. IVent to Italy, 1834, where he remained four years. Modelled statue of Queen Victoria, 1845; Prince Consort, I 847 ; Marquis of Hastings, for Malta, 1848.

\section{B $55^{\circ}$}

Battle of the Centaurs and Lapithæ.

From original model. Reproduced in Academy Album.

Presented by the Artist, 1836 . 


\section{CONTINENTAL SCULPTURE BEFORE THE NINE- TEENTH CENTURY

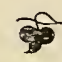

Antique.

C 600

Ceres. Colossal Statue, Mutilated.

Marble.

Brought from Megara, Greece. Over main doorway of Academy, outside.

Presented by Commodore Daniel F. Patterson, 1828 .

\section{601}

Bacchus and Young Satyr.

Marble.

\section{602}

Diana of Gabii.

Marble.

Reduction.

\section{603}

Flora.

Marble.

Bacchus and Ariadne.

$$
\text { C } 604
$$

Marble.

Amazon of the Vatican.

\section{605}

Original attributed to Phidias.

Marble.

\section{606}

Sitting Mercury.

Bronze.

Reduction from antique in Museum at Naples.

Presented by Alex. Fullerton, 1885 . 


\section{607}

Sleeping Hermaphrodite.

Marble.

Bequeathed by Mrs. Eliza Howard Burd, i 860.

\section{608}

Bust of Caracalla.

Marble
C 609

Head of Sappho.

Marble

C 6ro

Bust of Commodus.

Marble.

C 6II

Bust of a Daughter of Niobe.

Marble.

\section{612}

Bust of a Son of Niobe.

Marble.

C 613

Bust of Minerva.

Marble.

C $6 I_{4}$

The Wounded Achilles.

Plaster.

C 6 I 5

The Dying Lioness. Assyrian.

Plaster.

\section{616}

The Winged Victory.

Plaster.

Called Nike from Samothrake. Original found in the island of Samothrake, I863, by M. Champoiseau, French Consul at Adrianople, and transported to Paris, where it now rests in the Louvre. Part of a votive offering erected in the sanctuary of the Great Gods on the island of Samothrake. It stood upon a huge pedestal in the form of a ship's prow, where the Victory was represented as rushing forward in the excitement of battle, carrying a mast in one hand and holding a long trumpet to her lips with the other. The statue and pedestal commemorated the naval victory of King Demetrios Poliorketes of Macedonia over Ptolemy I. of Egypt, 306 B. C.

Presented by John Struthers, I 894. 


\section{Antonio Canova.}

Born in Possagno, November I, 1757; died in Venice, October I3, 1822. Studied with Toretto. Went to Rome in $\mathbf{I} 780$. Visited Paris at the request of Napoleon, and was received with great honor. Modelled a colossal statue of the Emperor. Was made a Member of the Institute. Received the title of Marquis of Ischia, I8I6, with an annual pension of three thousand pounds. Executed a statue of Washington for the State of North Carolina, I8I8.

Dancing Girl Reposing.

\section{C $6 \mathrm{I}_{7}$}

\section{618}

Colossal Head of Napoleon.

Marble.

Presented by Joseph L. Moss, 1847.

\section{Giuseppe Ceracchi.}

Born in Rome, July 4, I75I ; executed January 3I, I80I. He came to Philadelphia in I79I, and made busts of eminent Americans; also of Napoleon in 1796. When Italy was invaded by Napoleon in ISoo, he was detected in a plot to assassinate the First Consul, and was guillotined.

\section{619}

Bust of Alexander Hamilton.

Marble.

C 620

Bust of Benjamin Franklin.

Marble.

\section{Claude Michel Clodion.}

Born in Nancy, France, December 20, I745; died in Paris, March 28, I8I 4.

C 621

Bacchante, Dancing.

Marble. 


\section{622}

Bacchante and Young Satyr.

Marble.

Group. Original in the Louvre.

\section{Donatello (Donato di Niccolò di Betto Bardi).}

Born in Florence, $\mathrm{I} 385$; died in same city, 1468 . Began his professional career at an early age. Considered one of the greatest sculptors of the Renaissance, and the prototype of Michael Angelo.

\section{623}

Statue of St. George.

Plaster.

\section{624}

Madonna and Child.

Plaster.

C 625

Angels.

Plaster.

\section{François Victor Gevelot.}

Born in Paris, September 20, I79r. Studied with Delaistre, Bosio, and Gros, and at the École des Beaux-Arts.

\section{626}

Bust of William Strickland, $18{ }_{3} 6$.

Plaster.

\section{Lorenzo Ghiberti.}

Born in Florence, 1378 ; died 1455 ; supposed to have received instructions from Gherardo Starnini. Left his native city on account of the plague, 1400 , but was recalled in $\mathbf{I} 4 \mathrm{O}$ to execute the gates of the Baptistery, two of which occupied him for more than forty years and have been the pride of his country and the admiration of the world for more than four hundred years. 


\section{627}

East Gate of the Baptistery of St. John in Florence. Plaster.

From the original bronze. The ten compartments represent the following Biblical scenes: No. I, The Creation of Adam; No. 2, Adam and Eve, with Cain and Abel; No. 3, Noah with his family issuing from the Ark; No. 4, The appearance of the three angels in the Valley of Mamre, and Abraham's sacrifice of Isaac; No. 5, Birth of Isaac's sons, Esau and Jacob; No. 6, Joseph cast by his brethren into the well, his deliverance, and his interpretation of Pharaoh's dream ; No. 7, Moses on Mount Sinai ; No. 8, Joshua proceeding against Jericho; No. 9, David and Goliath; No. Io, The Queen of Sheba visiting King Solomon.

\section{Jean Antoine Houdon.}

Born in Versailles, March 20, I741 ; died in Paris, July 16, 1828. Studied in Paris. Gained the Grand Prize in $\mathbf{1} 76 \mathbf{r}$, and went to Rome, where he remained for ten years. In $\mathbf{1 7 8 5}$, at the solicitation of Franklin and Jefferson, came to America, where he executed a statue of Washington for the State capitol at Richmond, Va. Member of the Institute, I796. One of the most distinguished of modern sculptors.

Bust of John Paul Jones.

C 628

Signed, houdon. f. I 780 .

Plaster.

\section{629}

Bust of Joel Barlow, I804.

Plaster.

\section{Michelangelo Buonarroti.}

Born in Castel Caprese, near Florence, March 6, I475; died in Rome, February 18,1564 . Studied with Domenico and David Ghirlandaio. Admitted to the Medicean Academy of Art, 1489. Invited to Rome by Cardinal San Giorgio, I496. Employed by Julius II., Leo X., Adrian, Clement VII., and Paul III., on many important works: fresco of the Sistine Chapel in the Vatican, Moses, The Captive, and the dome of St. Peter's. Poet, painter, sculptor, and architect.

\section{630}

Madonna.

Plaster. 


\section{Luca della Robbia.}

Born in Florence, I400; died I48I. Apprenticed to a goldsmith, from whom he learned drawing and modelling. Executed the reliefs on the north side of the Campanile, Florence; the marble frieze of the organ gallery; and the bronze door for the old sacristy of the cathedral.

\section{631}

Madonna and Child.

Plaster.

\section{632}

Seven Boys Singing from one Book.

Plaster

From the Frieze of the Organ Screen in Duomo, Florence.

\section{633}

Five Boys Singing from one Scroll.

Plaster.

From the Frieze of the Organ Screen in Duomo, Florence.

\section{634}

Six Boys Playing on Trumpets and

Four Children Dancing.

Plaster.

From the Frieze of the Organ Screen in Duomo, Florence.

\section{635}

Five Boys Playing on Drums and

Four Children Dancing. Plaster.

From the Frieze of the Organ Screen in Duomo, Florence.

\section{Adam Scipione Tadolini.}

Born at Bologna, Italy, I789; died I870. Pupil of Canova. Professor of Academy of Bologna.

$$
\text { C } 636
$$

The Beautiful Georgian Surprised at the Bath.

Marble.

Suggested by an episode from an Oriental story. Maria, famous for her beauty, is overtaken while bathing by the youth sent out to rescue her from captivity.

Loaned by Mrs. Seth B. Stitt, 1893. 


\title{
CONTINENTAL SCULPTURE NINETEENTH CENTURY
}

\author{
Francesco Barzaghi.
}

Born in 1839. Studied at the Academy of Milan. The Emperor of Austria granted him a three years' pension, 1857. Knighted by the King of Portugal for his statue of Dom Pedro; also knighted and decorated by the present King of Italy.

\section{700}

Pharaoh's Daughter finding Moses.

Marble.

Group. Signed, F. Barzaghi, Milano, 1876.

Presented by Gustavus S. Benson, i 876 .

\section{Aristodéme Costoli.}

Born in Florence, 1803; died in 1871. Professor of the Academy of Fine Arts at Florence.

\section{701}

Columbus Discloșing the New World to the Old. Marble.

Group. Signed, A. Costoli di Firenze, I860.

Presented by the children of J. Francis Fisher, I 890.

\section{Augustus Kiss.}

Born in Pless, March, 1802; died in Berlin, March 25, 1865. Studied at the Berlin Academy under Rauch. Exhibited his group, Amazon Struggling with a Panther, which made him famous, 1839. Member and Professor of the Berlin Academy. 


\section{702}

Amazon Struggling with a Panther.

Bronze.

Reduction from the colossal group in Berlin. Carey Collection.

\section{703}

Equestrian Statue of Frederick the Great.

Plaster.

From the original model.

\section{Lombardi.}

D 704

Deborah.

Marble.

Signed, Lombardi, Roma, I 873.

Presented by Morris Patterson, I874.

\section{Rinaldo Rinaldi.}

Date and place of birth unknown; died in Rome, July 28, 1873. Studied with Canova.

\section{Penelope.}

\section{705}

Signed, Rinaldo Rinaldi, Roma, i 85 I.

Marble.

Presented by J. Rhea Barton, I8; I.

\section{Carl Steinhauser.}

Born in Bremen, $\mathbf{I} 8 \mathbf{I}_{3}$. Sent at an early age to Berlin for study under Rauch. Went later to Rome, where he received instruction from Thorwaldsen.

$$
\text { D } 706
$$

Hero and Leander.

Group. Signed C. Steinhauser, F., Roma, I847. Engraved by John Sartain. 


\title{
The Shell Girl.
}

\section{707}

Signed, C. Steinhauser, fec., Roma, I 840. Carey Collection.

\section{708}

Boy Playing Jackstones.

Marble.

Signed, C. Steinhauser, fec., Roma, 1841. Carey Collection.

\section{R. Trentanove.}

\author{
D 709 \\ Bust of Washington. \\ Signed, R. Trentanove, fcce., Rome, I 827. \\ Presented by Mrs. Aspinwall, 1877.
}

Marble. 


\section{SCULPTURE \\ L O A N E D}

L I. Excelsior.

John J. Boyle.

Artist, owner.

L 2. Mrs. Francis Peters.

Isaac Broome.

Mrs. Barstow, owner.

L 3. Statuette.

Saunders Lewis, owner.

J. B. Carpeaux.

L 4. Death and Honor. Group.

P. J. Connelly.

Artist, owner.

L 5. Venus. Statuette.

John Gibson.

James H. Campbell, owner.

L 6. Rebecca.

Lombardi.

Harry Godey, owner.

L 7. Ruth.

Lombardi.

Mrs. Rowland Seeger, owner.

L 8. Ruth.

Randolph Rogers.

James Douglas, owner.

L 9. Nydia, the Blind Girl of Pompeii.

Randolph Rogers.

James Douglas, owner.

L Io. Eve. Statuette.

Rinaldo Rinaldi.

James H. Campbell, owner.

L II. Francis Peters.

Salomon.

Mrs. Barstow, owner. 


\section{HARRISON EARLE COLLECTION LOANED}

\section{GALLERIES A AND I}

L I2. A Mother's Joy.

L 13. In the Studio.

L 14. The Ferry.

L I5. A Shady Retreat.

L I6. Rural Pleasures.

L 17. Rural Retirement.

L 18. Signal in the Park.

L Ig. The Evening of Life.

L 20. The Morning Walk.

L 2I. The Hunter's Rest.

L 22. Sheep at Pasture.

L 23. Fruit and Glass.

L 24. Roadside Inn near Munich.

L 25. On the Shore of Chiem Lake.

L 26. Seeking Shelter from the Storm.

$$
96
$$

W. Amberg.

Arnoud.

Bakhuyzen.

Bakhuyzen.

D. Baron.

D. Baron.

Carl Becker.

L. Blaise.

H. Breling.

G. W. Brenneman.

Erissot.

Wm. M. Brown.

A. F. Bunner.

A. F. Bunner.

H. Burkel. 
L 27. Halt for Refreshments.

L 28. Charge of Cuirassiers at Reichsofen.

L 29. Blighted Prospects.

L 30. The Music-Lesson.

L 31. Cattle, British Channel.

L 32. Grandmother's Lesson.

L 33. Village Minstrel.

L 34. On the Danube.

L 35. First Visit to School.

L 36. Crossing the Brook.

L 37. "Is it true, Grandmother?"

L 38 . One more Kiss.

L 39. Settling the Market Money.

L 40. The Doll's Trousseau.

L 4I. Visit to My Neighbor.

L 42. Closing the Bargain.

L 43. Lady Reading a Letter.

L 44. Starting for the Chase.

L 45. On the Seine, near Paris.

L 46. Springtime.

L 47. Portrait of a Lady.

L 48. Maternal Felicity.
H. Buttner.

E. Charpentier.

J. J. Cool.

Ed. d'Apvril.

H. W. B. Davis.

De Block.

F. de Brakeleer.

A. de Bylandt.

Th. de Heuvel.

Léon Delachaux.

Léon Delachaux.

Léon Delachaux.

Léon Delachaux.

Léon Delachaux.

Léon Delachaux.

Léon Delachaux.

De la Hoese.

A. de Molins.

A. Defaux.

Carl Dircks.

Jacob Eichholtz.

Rudolph Epp. 
L 49. Jerusalem from the Mount of Olives.

B. Fiedler.

L 50. Château Egremont, with Landscape,

L. Fleury.

L 5 I. Life in the Vaterland.

Carl Geibel.

L 52. Lumbering in the Black Forest.

Carl Geibel.

L 53. Return from the Harvest-Field.

Th. Gerard.

L 54. Domestic Happiness.

Gesselchap.

L 55. In the Tyrol.

B. Girsche.

L $5^{6}$. Sunset in Belgium.

B. Girsche.

L 57. "Cherries Ripe."

Virginia Granbery.

L 58. The Last Toast.

C. J. Grips.

L 59. Gallic Archers.

Guinier.

L 6o. The Studio.

Theo. Hanrath.

L 6r. Scene in Southern Tyrol.

H. Hartwich.

L 62. After the Brawl.

E. Harvey.

L 63. Near Los Angeles, California.

H. Herzog.

L 64. Shrimp-Fishing, Holland.

H. Herzog.

L 65. Environs of Rome.

Albert Hertel.

L 66. Forest Interior in the Alleghanies.

George Hetzel.

L 67. Game.

George Hetzel.

L 68. The Welcome News.

T. Hildebrandt.

L 69. On the Italian Coast.

Hilverdonck.

L 70. Castle on the Rhine.

Ch. Hoguet. 
L 71. Captured Banditti

L 72. How the Case was Won.

L 73. The Music-Lesson.

L 74. Tired Out.

L 75. Getting a Ride.

L 76. Sheep Pasture.

L 77. A Garden Retreat.

L 78. The Proposal.

L 79. Old Canal near Amsterdam.

L 8o. On St. John's River, N.B.

L 8I. Tyrolese Peasants preparing for Church

L 82. The Pet Parrot.

L 83. Chickens in a Barnyard.

L 84. Rabbits and Chickens.

L 85. Waiting for a Chance.

L 86. Flowers.

L 87. Portrait of a Gentleman.

L 88. Portrait of a Lady.

L 89. Interior of a Church.

L 9o. Grandmother's Pet.

L 9I. Stable Interior, with Sheep.

L 92. Off for the Hawking.
L. Holmberg.

Carl Hübner.

Ch. Hue.

A. Jernberg.

Francis C. Jones.

H. Bolton Jones.

L. Joulin.

Fr. Keller.

Kluyver.

F. W. Kost.

F. Kraus.

Lasalle.

E. R. Maas.

E. R. Maas.

E. R. Maas.

Marie Molyn.

John Neagle.

John Neagle.

J. Nicolie.

Joh. J. Paling.

Ravenswaay.

W. Rauber. 
L 93. Content in a Cottage.

L 94. Interior of a Stable.

L 95. Curiosity.

L 96. On the Seine.

L 97. Right in the Bull's Eye.

L 98. The Old Beau.

L 99. Fishing Coast near Dover, England.

L Ioo. Industry and Idleness.

L ror. "I know it."

L 102. Preparing for Dinner.

L ro3. Prussian Troops on the March.

L I04. Hide-and-Seek.

L ro5. The Official Visit.

L I06. Wounded Bear-Hunter.

L 107. Inquiring the Way.

L I08. Street in Amsterdam.

L rog. View on the Scheldt, with Cattle.

L Iro. Still Water at Evening.

L III. Night Market in Amsterdam.

L II2. Distracted Attention.

L Ii3. The Goat's Birthday.

L I14. Winter Sports in Holland.
Rikkers.

Henrietta Ronner.

W. Rorgge.

J. Rozier.

F. Schlesinger.

Antony Serres.

W. Shayer, Sr.

W. H. Snyder.

Sondermann.

Stroebel.

Swebach.

Taanman.

H. Tenkate.

A. Tidemand.

M. Tilmes.

E. P. v. Bommel.

E. Van Damme.

A. Vandeventer.

G. van Hamme.

Van Hove.

H. Van Seben.

H. Van Seben. 
L II5. Resting by the Way.

L II6. Market Scene by Moon and Candle Light.

L 117. Market Scene by Moon and Candle Light.

L II8. Interior of a Stable.

L IIg. The Thief Detected.

L I20. The Disputed Reckoning.

L I2r. Cattle in a Stable.

L 122. Drove of Cattle at Evening.

L 123. Milking, Early Morning.

L 124. Shepherd and Sheep.

L I25. The Watering-Place.

L 126. View in Westphalia.

L 127. Moonlight in the Black Forest.

L 128. In Bohemia. Twilight.

L 129. View on Lake Bolsena.

L 130. Old Homestead, Montgomery County.

L I3I. The Shepherd's Return at Evening.

L I32. Twilight near Darmstadt.

L 133. View near Etzenhausen.

L 134. View in Bohemia, with Cattle.
H. Van Seben.

P. van Schendel.

P. van Schendel.

W. Verschuur.

W. Verschuur.

Vetten.

A. Vogt.

W. T. v. Starkenborgh.

W. T. v. Starkenborgh.

W. T. v. Starkenborgh.

W. T. v. Starkenborgh.

J. N. T. v. Starkenborgh.

Aug. Weber.

Aug. Weber.

Aug. Weber.

Carl Weber.

Carl Weber.

Carl Weber.

C. Philipp Weber.

C. Philipp Weber. 
L I35. After Rain, near Munich.

L I36. Cattle. Coming Storm.

L 137. Early Spring in Dacon Moors.

L 138. Return of the Drove at Evening.

L I39. View near Unterstein

L I40. View of Kaiser's Wall.

L I4I. Stream in the Catskills.

L 142. The Drover's Return at Evening.

L I43. Scene on Steffel Lake.

L 144. Sunset in Illinois.

L I45. View in Homburg Park.

L 146. The Forge of Chittenfold, Surrey, England.

L I47. Spanish Smugglers.

L 148. Seeking Shelter from the Coming Storm.

L I49. 'The Sheepfold.

L I50. The Shepherd's Rest.
Paul Weber.

Paul Weber.

Paul Weber.

Paul Weber.

Paul Weber.

Paul Weber.

Paul Weber.

Paul Weber.

Philipp Weber.

Philipp Weber.

Philipp Weber.

E. C. Williams.

Jules Worms.

H. Zügel.

H. Zügel.

H. Zügel. 


\section{HONORS AWARDED BY THE TEMPLE FUND क्ष}

From I 884 until 1890 the Temple Gold Medal was awarded by the Directors of the Academy to the best figure picture, and the Temple Silver Medal to the best landscape and marine. In $\mathrm{i} 89 \mathrm{I}$ and $\mathrm{I} 892$ the medals were awarded by the Jury of Selection and Hanging Committee of Artists to the best and second best pictures, irrespective of subject. In 1893-94 two Gold Medals were awarded.

\section{Temple Gold Medal.}

I884. George W. Maynard.

1885. Charles Sprague Pearce. I887. Clifford Provost Grayson. I888. Charles Stanley Reinhart. r889. Anna Elizabeth Klumpke.
I 89o. William Henry Howe.

I891. Abbott H. Thayer.

1892. Henry S. Bisbing.

I893. J. McNeil Whistler.

I893. John S. Sargent.

\section{Honorable Mention.}

I887. Lucy D. Holme.

I889. Robert Blum.

Anna Lea Merritt.

\section{Temple Silver Medal.}

I883. William Thomas Trego.

I884. Thomas Hill.

I885. William T. Richards.

1887. Alexander Harrison.

I888. Howard Russell Butler.
I889. Arthur Parton.

r89o. Edward L. Simmons.

I89I. Kenyon Cox.

I892. George Inness.

\section{Honorable Mention.}

I887. William T. Richards.

I887. William Sartain.
I891. Robert Reid.

I891. Theodore Robinson.

I 89I. George H. Bogert.

\section{AWARD OF THE ACADEMY GOLD MEDAL OF HONOR}

Founded in I 893 by John H. Converse, Esq., of the Board of Directors of the Academy. 


\section{The Pennsylvania Academy of the Fine ARts}

\section{ALBUM \\ eै}

REPRODUCTIONS OF SELECTED WORKS IN THE PERMANENT COLLECTION OF THE ACADEMY.

\section{THIRTY PLATES. \\ PRICE, ONE DOLLAR.}

The Academy has recently issued the above work, containing thirty full-page Levytype plates. Each plate is accompanied by a page of text, biographical, descriptive, and critical. The size of the page, I I $\mathrm{x}$ I4, gives ample scope for a satisfactory reproduction, and this, with the quality of the paper and character of the press-work, renders the volume worthy of preservation as a record of the Academy and as a work of rare beauty. The examples reproduced are by:

$\begin{array}{lll}\text { GOZZOLI, } & \text { SULLY, } & \text { RICHARDS, } \\ \text { VAN DER HELST, } & \text { KRIMMELL, } & \text { DURAN, } \\ \text { WILSON, } & \text { LESLIE, } & \text { WYLIE, } \\ \text { WEST, } & \text { NEAGLE, } & \text { JANSSEN, } \\ \text { PEALE, } & \text { LOUGH, } & \text { BRIDGMAN, } \\ \text { STUART, } & \text { WITTKAMP, } & \text { KOEHLER, } \\ \text { VANDERLYN, } & \text { MAY, } & \text { PICKNELL, } \\ \text { COLLINS, } & \text { BOUGUEREAU, } & \text { DAVIS, } \\ \text { ALLSTON, } & \text { GASTALDI, } & \text { TREGO, } \\ & \text { FARUFFINI. } & \end{array}$

\section{FOR SALE AT THE DESK.}





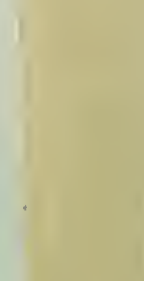

